IZA DP No. 4435

Racial Differences in Fringe Benefits and Compensation

Wallace Mok

Zahra Siddique

September 2009 


\title{
Racial Differences in Fringe Benefits and Compensation
}

\author{
Wallace Mok \\ Chinese University of Hong Kong \\ Zahra Siddique \\ IZA
}

\section{Discussion Paper No. 4435 \\ September 2009}

\author{
IZA \\ P.O. Box 7240 \\ 53072 Bonn \\ Germany \\ Phone: +49-228-3894-0 \\ Fax: +49-228-3894-180 \\ E-mail: iza@iza.org
}

\begin{abstract}
Any opinions expressed here are those of the author(s) and not those of IZA. Research published in this series may include views on policy, but the institute itself takes no institutional policy positions.

The Institute for the Study of Labor (IZA) in Bonn is a local and virtual international research center and a place of communication between science, politics and business. IZA is an independent nonprofit organization supported by Deutsche Post Foundation. The center is associated with the University of Bonn and offers a stimulating research environment through its international network, workshops and conferences, data service, project support, research visits and doctoral program. IZA engages in (i) original and internationally competitive research in all fields of labor economics, (ii) development of policy concepts, and (iii) dissemination of research results and concepts to the interested public.
\end{abstract}

IZA Discussion Papers often represent preliminary work and are circulated to encourage discussion. Citation of such a paper should account for its provisional character. A revised version may be available directly from the author. 
IZA Discussion Paper No. 4435

September 2009

\section{ABSTRACT \\ Racial Differences in Fringe Benefits and Compensation*}

This paper examines differences in two important components of non-wage compensation, employer provided health insurance and pensions, across African Americans and the whites in the United States. Using data from the Current Population Survey (CPS) and the National Longitudinal Survey of Youth (NLSY), we study the recent trends in the recipiency of this non-wage compensation across race groups. Our results show that African American men on average are significantly less likely to receive employer provided health insurance and pension than whites in the last decade. We also find that the inclusion of racial differences in ability as measured by the Armed Forces Qualification Test (AFQT) score reduces the unexplained racial gap in fringe benefit offers, highlighting the importance of human capital variables in fringe benefit recipiency. Finally, we re-examine racial inequality in the labor market by examining within-group inequality in compensation over the last decade and also the role of ability in between-group inequality in compensation.

JEL Classification: $\quad 111, \mathrm{J15}, \mathrm{J32}$

Keywords: economics of minorities and races, non-wage labor costs and benefits

Corresponding author:

Zahra Siddique

IZA

P.O. Box 7240

53072 Bonn

Germany

E-mail: siddique@iza.org

\footnotetext{
* We are grateful to Barry Chiswick, Christopher Taber and seminar participants at the 2009 joint IZA/SOLE conference, the IZA Brownbag seminar and the 2009 European Economic Association conference for comments and discussion. All errors are our own.
} 


\section{Introduction}

Racial gaps in the labor market have persisted, and in some cases, have even increased recently (for example see Altonji and Blank[1]). Racial differences in wages are fairly well documented; however, there is less work examining the racial differences in non-wage compensation such as employer-provided health insurance and pension coverage. This paper seeks to ask several questions: What are the racial differences in fringe benefits such as health insurance and pension coverage for men and women? What component of the racial difference in health insurance and pension coverage can be explained as a result of racial differences in characteristics? What are the racial differences in total compensation, and how do these differ from racial differences in wages?

To date, little work examines racial differences in non-wage compensation. Even and Macpherson[15] examine gender differences in pensions and find that about two-thirds of the gender gap is explained by differences in observable worker characteristics. Solberg and Loughlin[38] use NLSY91 to examine gender inequality by estimating an index of the value of compensation rather than wages only; they find that this reduces the overall gender gap, but that the gap remains significant. They find racial gaps in total compensation to be insignificant after controlling for other characteristics. Monheit and Vistnes[30] examine changes in insurance coverage by race, ethnicity and gender using the 1987 National Medical Expenditure Survey and the 1996 Medical Expenditure Panel Study. They find that for most groups, declines in coverage between 1987 and 1996 are not explained by changes in observable variables. They also find that most of the gap between Hispanic and white men in 1996 is explained by differences in observable characteristics such as wages, family income, and education. Dushi and Honig[13] use the 1996 Survey of Income and Program Participation to examine racial differences in health insurance coverage and find that minorities have significantly lower rates of insurance coverage than whites. Levy[27] uses the Current Population Survey to examine racial and gender differences in health insurance and finds that the inclusion of health insurance results in a smaller estimate of gender compensation inequality than one that is based solely on wages. Our work contributes to the literature by further examining racial and gender differences in offers of pension coverage as well as health insurance using data from both the Current Population Survey (CPS) and the National Longitudinal Survey of Youth (NLSY). Use of the NLSY allows us further to examine the role of ability in fringe benefit offers; to our knowledge, this is the first study that examines the role of ability in racial differences in fringe benefits using NLSY data.

A further important contribution we make is to the literature on compensation inequality. Compensation inequality gives a more relevant concept for understanding well-being than wages alone. There is recent literature (see for instance work by Pierce[35] and Chung[7]) which finds that the dispersion of total compensation (measured as the difference between percentiles of the compensation distribution) exceeds 
the dispersion of wages, and that compensation inequality has grown more in recent years than has wage inequality.

We find that white men have significantly higher offers of health insurance coverage and of pension coverage than do African American men. Differences in workplace characteristics favor higher offers of health insurance and pension coverage for African American men in the CPS, so that controlling for workplace characteristics such as union membership and firm size increases the racial differences in fringe benefit recepiency at the extensive margin. For women, we dont find racial differences in fringe benefits to be large. However, controlling for racial differences in ability (using AFQT test scores) in the NLSY data, we find that much of the unexplained racial difference in fringe benefit recepiency at the extensive margin for men disappears. For women, we find that once we control for racial differences in ability African American women are more likely to get fringe benefits than white women. This analysis highlights the importance of racial differences in human capital measures such as ability in explaining racial differences in fringe benefit recepiency.

We also use the data on fringe benefit offers to estimate total compensation by including the value of wages, health insurance and pension coverage. Using the CPS data over the last decade, we find that non-wage compensation inequality is greater among African Americans than among whites and that the dispersion in non-wage compensation and compensation is also greater among African Americans than whites over the last decade. We also use quantile decompositions to examine the role of ability in racial differences in compensation. We find that inclusion of ability in the set of characteristics that are allowed to vary across groups reduces the unexplained difference in non-wage compensation (as well as wages and compensation) between African Americans and whites at all points of the non-wage compensation distribution. Thus, racial differences in ability play a role at the intensive as well as extensive margins of non-wage compensation.

In section 2, we begin with a discussion of the empirical facts about fringe benefits and the economics behind these benefits. In Section 3, we discuss the datasets used in this study. In Section 4, we consider the issue of fringe benefit take-up and look at the descriptive statistics on fringe benefits recipiency by racial and gender groups. In Section 5, we examine in detail how different individual and firm level characteristics explain the racial difference in fringe benefit recepiency at the extensive margin. In Section 6, we examine compensation inequality for African Americans and whites over the last decade as well as the role of ability in racial differences in compensation. Section 7 discusses a series of caveats and ideas for future research and Section 8 concludes. 


\section{Fringe Benefits}

\section{IIa. Fringe Benefits in the United States}

The fraction of employee total compensation attributed to fringe benefits has been rising in the last few decades. Table 1 shows the average employer-cost per hour worked and the amount of which is paid for fringe benefits between 1997 and 2008. The data are published by the Department of Labor, and are based on civilian employment. In 1997, fringe benefits constituted only about 16 percent of the average employee's total compensation, but this percentage had risen to about 20 percent by 2008 . We discuss two of the most popular fringe benefits studied in this paper - employer provided health insurance, and pension plans.

\section{IIa.i. Health Insurance}

Table 1 reveals also that employer-provided health insurance has become a rising cost to the employer - in 1997 it constituted 5.9 percent of the hourly average cost, but had risen to 8.4 percent by 2008. Health insurance is also a significant part of all fringe benefits paid - about 42 percent of fringe benefits were due to health insurance. Health Insurance is often provided by an employer, the employee will normally be asked to pay a fraction of the total premium cost with the rest of the sum paid by the employer. Pierce[35] estimates that in 1997 about 73 percent of jobs have some forms of health insurance that require employer contributions. Health Insurance has been an important part of the employee's total compensation, especially for those who would be ineligible to purchase it privately (e.g. due to pre-existing conditions). ${ }^{1}$ The cost of an average health insurance policy has risen significantly in the last 10 years - data from the Kaiser/HRET Survey of Employer Sponsored Health Benefits[26][25] suggest that the average annual premium for single health insurance coverage has more than doubled between 1999 and 2008, rising from 2,916 dollars to 4,704 dollars in nominal terms. Average annual premiums for family coverage have also risen by a similar percentage, from 5,791 dollars in 1999 to 12,680 dollars in 2008. In terms of the costs borne by the employers, the average per-employee health insurance premium contribution has risen from 1,878 dollars (86 percent of the total premium) in 1999, to 3,983 dollars (85 percent of the total premium) in 2008. These data suggest that employer provided health insurance has become more valuable to the average employee, and represent a greater proportion of his total compensation over the last ten years.

\section{IIa.ii. Pension Plans}

Pierce[35] estimates that pension amounts to about 3 percent of the employee's total compensation. Columns 6-8 of Table 1 also show that the cost to the employer in providing pension has increased, from 75 cents in

\footnotetext{
${ }^{1}$ Pierce[35] also has estimated that in 1997, employer-provided health insurance constitutes about 5.4 percent of the employee's total compensation.
} 
1997 (per hour worked) to $\$ 1.26$ in 2008 . However, as a fraction of total fringe benefits, the cost of pension has remained steady at around 21-23 percent.

\section{IIb. Reasons for Employer Provision of Fringe Benefits}

There are several reasons for why employers choose to provide these fringe benefits and why employees choose to accept these benefits ${ }^{2}$ :

1. Cost Advantage - In accordance with the 1943 Internal Revenue Code, compensation in the form of health insurance and pensions are tax deductible for the employer.

2. Risk Pooling - The fact that health status is an unobservable variable implies that the individual may find it cheaper to purchase health insurance through their employers selected schemes. Other than public health insurance which is not universal, those who cannot or cannot afford to purchase health insurance may find employer-provided health insurance the only way of getting insured.

3. Productivity - If the productivity of a company is positively correlated with the health of its workforce, then providing health insurance is certainly important to the firm's profitability.

4. Human Resource Management - Fringe benefits may give an impression to the employees that by losing their job, they will lose more than their wages. Those whose entire family is covered by employerprovided health insurance may find it especially costly to quit their job. Since the cost to the employer in providing these benefits is lower due to risk pooling (or group discounts), it is a cost-effective human resource control tool.

\section{Data}

We primarily use two different datasets in our analysis. First, we use the 1996-2006 data from the Annual Demographic File/Annual Social and Economic Supplement to the Current Population Survey (CPS) to examine the trends in the recipiency of employer-provided pension and health insurance. Second, we use data from the National Longitudinal Survey of Youth (NLSY) to analyze racial differences in the recipiency of these benefits. Three additional datasets are used to aid our analyses of employer provided health insurance take-up, and for the imputation of the values of these fringe benefits. Additional descriptions of these datasets will be provided in their respective sections.

\footnotetext{
${ }^{2}$ In addition to the following reasons Woodbury [40] also discusses the impact of rising unionization, changing age structure of the labor force and rising income as the reasons behind the rise in proportion of total compensation going to fringe benefits over the 1960s and 1970 s
} 


\section{IIIa. The Current Population Survey (CPS)}

The CPS is a monthly survey of about 60,000 nationally representative households. Our data come from a further supplement questionnaire was administered in March of each year. This supplement, known as the Annual Social and Economic Supplement (ASEC), ${ }^{3}$ provides additional data on work experience, income for the previous year, non-cash benefits received, and employment situations. We use the 1996-2006 ASEC in this study.

The pension recipiency indicator that we use in our analysis comes from two questions asked of all CPS interviewees: 1) Other than social security did the employer or union that the interviewee worked for in (the previous year) have a pension or other type of retirement plan for any of the employees? 2) Was he/she included in that plan? Exactly how we define recipiency of employer-provided pension will be discussed below.

For employer-provided health insurance, individuals are asked: At any time in (previous calendar year), (were you/was anyone in this household) covered by a health insurance plan provided through (their/your) current or former employer or union? The CPS ASEC also collect information about the specifics of the plan, such as how the plan was paid (in part or full), and how much the contribution the employer made (if the individual was covered by employer provided health insurance). Note that these questions do not address the issue of 'Take-Up' - an individual may be offered employer-provided health insurance but decides to decline the offer, and thus he would answered that he is not covered by employer-provided health insurance. We shall return to this issue below.

\section{IIIb. The National Longitudinal Survey of Youth (NLSY)}

We also use the 1979 cohort of the National Longitudinal Survey of Youth (NLSY79). The NLSY79 is a panel study of a sample of 12686 young men and women who were 14-22 years old when they were first interviewed in 1979. ${ }^{45}$ Since then, they have been re-interviewed yearly from 1979 to 1994, and bi-annually since 1996. The NLSY79 documents each respondent's experience, mainly with the labor market- such as labor market attachment, training and education. A particularly attractive feature of using the NLSY79 to analyze wage differentials is that it provides a proxy for the individual's ability - the Armed Forces Qualification Test (AFQT) score. In 1980, over 90 percent of the NLSY79 respondents were given a set of 10 tests from the Armed Services Vocational Aptitude Battery (ASVAB) ${ }^{6}$ and a subset of 4 of these tests

\footnotetext{
${ }^{3}$ The ASEC was called Annual Demographic Supplement (ADF) prior to 2003.

${ }^{4}$ The sample size diminished over time due to funding limitation. Sample size of the survey dropped from 12686 respondents in 1979 to 10436 respondents in 1990.

${ }^{5}$ The NLSY79 is formally constituted by 3 subsamples: 1) A cross sectional sample of 6111 young people residing in US in 1979. 2) A supplemental sample of 5295 young people. This sub-sample is designed to over-sample hispanics, blacks and economically disadvantaged whites. 3) A sample of 1280 young people who were enlisted in one of the 4 branches of military as of 30th September 1978 .

${ }^{6}$ Formally, the tests in the ASVAB consist of (1) general science, (2) arithmetic reasoning, (3) word knowledge, (4) paragraph comprehension, (5) numerical operations, (6) coding speed, (7) auto and shop information, (8) mathematical knowledge, (9)
} 
constitutes the AFQT. The AFQT score is used by the military services to screen applicants and thereby assigning various jobs within the military. The use of the AFQT score as a measure of the ability of the individual has been fairly widespread in economics and sociology. ${ }^{7}$

We mainly focus the 1996-2004 periods, because many variables of interest, such as labor union status, employer pension provision, employer health insurance provision, are not available in the early waves of the survey. It is also important to point out that the results generated by the NLSY79 are not comparable with those of the CPS, because the sample in the NLSY79 is not nationally representative.

The questions in the NLSY regarding employer-provided health insurance and pension are phrased as follows: Did the employer MAKE AVAILABLE to you (type of benefit)?

\section{IIIc. Take-Up of Fringe Benefits- offer versus coverage rates}

A close examination of the wording of the fringe benefit questions in the CPS and the NLSY reveals that there are two different underlying concepts - offer and coverage. In the CPS, questions about whether the employer offers a pension plan are asked, but for health insurance, the individual is asked about whether he/she is 'covered' by such fringe benefit. For the NLSY, the questions ask whether a particular fringe benefit was offered by the employer.

This poses a non-trivial conceptual question - whether we should use the 'offer rate' or the 'coverage rate' as an indicator of recipiency as neither one of these questions address 'recipiency' directly. This issue arises because of the 'take-up' problem - a worker may not receive the benefit even if his employer offers him a plan. Intuitively, if most workers decide not to take-up these benefits because of endogenous reasons (such as his disliking of the plan, or that he/she is covered by other plans), then the racial difference in the offer rate might be a better measurement of inequality as it is the worker's own decision that led them not receiving the benefit and using the coverage rate understates the true level of recipiency. Similarly, if most workers are not taking up these benefits because of exogenous reasons (e.g. the worker is on a temporary contract and this ineligible for fringe benefits or that the insurance company refused to accept the worker because of his risk characteristics), then the racial difference in the coverage rate is a more valid measurement of inequality as the reasons for not receiving the benefit is beyond the worker's own control and using the offer rate overstates the level of recipiency. Moreover, if take-up behavior differs enormously between race groups, then using simply the difference in the offer rate/coverage rate between race/gender groups will bias the true level of inequality.

We use the Survey of Income and Program Participation (SIPP) to study whether there are racial differences in the take-up of employer-provided health insurance. For simplicity, we focus on health insurance

mechanical comprehension, and (10) electronics information.

${ }^{7}$ For example, see Neal and Johnson [33]. 
only. In future versions of this paper we hope to also look at reasons for not taking up employer-provided pension plan.

SIPP is a series of short panel datasets based on a sample of nationally representative non-institutionalized civilian population. Interviews are implemented every 4 months and individuals are asked to provide detailed demographic and income information for the 4 months prior to the interview month. ${ }^{8}$ Occasionally, SIPP interviewees are asked additional questions on a variety of topics such as health and physical well-being, financial history, etc in its topical modules. We use the wave 5 topical modules for both the 1996 and 2001 panels (these correspond to the year 1997 and 2003 respectively). In these topical modules, interviewees are first asked: Does your employer offer a health insurance plan to ANY of its employees?(Yes/No). For those who are not covered by employer-provided health insurance (as reported in the core questionnaire), the interviewer asks for the reasons of non-coverage. For this analysis, we restrict our sample to those who are 22-64 years of age and are working in private companies.

Table 2 presents the results. The upper panel (lower panel) tabulates the results for the 1996 panel (2001 panel). Columns 1-5 show the percentages of those who are not taking up employer-provided health insurance by various reasons (individuals can give more than one reason so the rows do not sum to one, and we also omit the 'other reasons' category). For those white men who are not taking up employerprovided health insurance, 29 percent in the 1996 panel did so because they are ineligible due to their type of employment (e.g. in temporary or part-time positions). For blacks, the rate is 37 percent. A small fraction of those who are offered health insurance did not take up because of being denied by the insurance companies. We also see that white men are more likely than black men to decide not to take-up because they are covered by other plans, while black men are more likely to decline employer-provided health insurance because the plans are too expensive.

These results suggest that 'ineligibility due to the type of employment' is the primary exogenous reason for non-takeup. Therefore, we believe that by restricting our attention to only on those who are working full-time, most of the non-takeup will be due to endogenous reasons. Thus, upon this restriction the offer rate is a better measure of fringe benefit recipiency.

Nevertheless, the CPS ASEC do not give us the employer-provided health insurance offer rates. Instead, questions about whether the individual's current employer offers health insurance are asked in the CPS February supplements. Unfortunately, these supplements are available only in some years (since 1996, they are available in 1997, 1999, 2001 and 2005). Given the CPS structure, we merge these February CPS data with the CPS ASEC, thus allowing us to have access to variables in both supplements for the individual. The cost of doing so is a sample reduction as we cannot use individuals who were interviewed in March but not February and vice-versa.

\footnotetext{
${ }^{8}$ Readers are encouraged to refer to U.S. Census Bureau (2001) for a more thorough description of SIPP.
} 
In these CPS February supplements, those who are not taking up employer-provided health insurance are also asked about the reasons for doing so. In appendix table A1, we report the percentage of those who are not taking up such benefit, by various reasons. We focus on those who are working full time and more than 35 hours per week. Indeed, upon making this restriction, we see that most of the non-takeups are doing so due to endogenous reasons.

\section{Trends in the provision and coverage of Fringe Benefits}

\section{IVa. Trends in the provision and coverage of Employer-Provided Health Insurance}

Table 3 shows the percentages of workers who are offered employer-provided health insurance using the February and March supplements of the 1997, 1999, 2001 and 2005 Current Population Surveys. We report these percentages for white men, African American men, white women and African American women separately. We restrict our sample to those 25-64 years of age who work over 35 hours a week in the private sector.

Overall, the percentage of workers who were offered health insurance by their employers has not changed significantly in the 1997-2005 period. However, we do observe a racial difference in the offer rates - in 1997 about 89 percent of white men worked in jobs that offer health insurance, while that percentage for African American men is only 85 percent. This gap persists over the 1997-2005 period. It is somewhat interesting to see that the racial gap exists for women in the recipiency of this fringe benefit is smaller than for men.

\section{IVb. Trends in Employer Provided Pension}

Table 3 also reports the percentages of workers who are offered a pension plan (defined contribution or defined benefit) in 1997-2005. Here we see that the racial gap in pension recipiency is much larger than that of health insurance. Both African American men and women are less likely to work in jobs that provide them a pension plan. In 1997, 70 percent of white male workers are offered pension plans, for African American male workers however, this percentage is about 65 percent. In 2005, the gap is wider with 69 percent and 62 percent for white and African American men respectively. For women, about 69 percent of white women and 67 percent of African American women are offered pension plans in 2005.

\section{Racial Differences in Fringe Benefit offers}

There are important differences in characteristics of individual African American and white workers as well as in the kinds of jobs that African American and white workers are working in. It is important to understand the role that individual and workplace characteristics play in whether or not workers are 
offered health insurance and/or pension by the employer. In addition, we are interested in the residual racial differences in fringe benefit offers that remain after we have controlled for differences in individual and workplace characteristics. In order to address these questions, we estimate simple probit regressions where we regress a set of individual and workplace characteristics on the fringe benefit dummy (either health insurance or pension offer) for male and female samples of the data.

The regressions we estimate are of the following type, which include race as well as other individual and workplace controls, separately for men and for women and for health insurance and pension offers:

$$
\begin{gathered}
C_{i}^{*}=Z_{i} d_{C}+e_{C, i} \\
C_{i}=\left\{\begin{array}{cc}
1 & \text { if } C_{i}^{*}>0 \\
0 & \text { if } C_{i}^{*}=0
\end{array}\right.
\end{gathered}
$$

$C \in\{H I, P\}$ is a dummy variable taking the value one if individual $i$ is offered non-wage compensation (health insurance HI or pension P) from the employer and the value zero if not, $C_{i}^{*}$ is a latent variable that determines whether or not an individual gets offered non-wage compensation (health insurance or pension) and $Z_{i}$ is the vector of individual and workplace characteristics that determine whether or not an individual gets offered health insurance and pension. We assume the error term $e_{C, i}$ is distributed normally so we carry out probit estimation of the above equations.

In addition to the regression analysis with race dummies, we also carry out the regressions on fringe benefit offers separately for each racial group and look at the differences across racial groups. In other words, we also report unexplained differences in fringe benefits (health insurance and pension) across racial groups separately for men and for women, by carrying out non-linear decompositions. Unlike the regression analysis which assumes the same returns to characteristics and traits for different racial groups, the decomposition analysis does not make this assumption.

The non-linear decomposition we use is a variant of the well-known Blinder-Oaxaca decomposition, as given by

$$
C^{W}-C^{B}=\left[\left(Z^{W}-Z^{B}\right) d_{C}^{W}\right]+\left[Z^{B}\left(d_{C}^{W}-d_{C}^{B}\right)\right]
$$

where (as above) $Z^{j}$ is the row vector of average values of the independent variables and $d_{C}^{j}$ is the vector of coefficient estimates for benefit type $C$ and race $j$. Since we want to estimate unexplained differences in a discrete binary variable, we use a modification of the method that decomposes the non-linear equation, $C=F\left(Z d_{C}\right)$, since $C$ does not necessarily equal $F\left(Z d_{C}\right)$. Following the method proposed in Fairlie[16], we use the non-linear decomposition given by 


$$
C^{W}-C^{B}=\left[\sum_{i=1}^{N^{W}} \frac{F\left(Z_{i}^{W} \delta_{C}^{W}\right)}{N^{W}}-\sum_{i=1}^{N^{B}} \frac{F\left(Z_{i}^{B} \delta_{C}^{W}\right)}{N^{B}}\right]+\left[\sum_{i=1}^{N^{B}} \frac{F\left(Z_{i}^{B} \delta_{C}^{W}\right)}{N^{B}}-\sum_{i=1}^{N^{B}} \frac{F\left(Z_{i}^{B} \delta_{C}^{B}\right)}{N^{B}}\right]
$$

In the above decompositions, the first term represents the part of the racial gap in fringe benefit offers which is due to group differences in distribution of $Z$; the second term represents the part of the racial gap due to differences in group processes determining the level of $C \in\{H I, P\}$. The second component is the part of the racial gap in fringe benefit offers which cannot be explained by the racial differences in individual and workplace characteristics.

In order to estimate the contribution of racial differences in individual characteristics using Fairlie (2005), the standard errors associated with these are estimated by the delta method. The decomposition method involves a one to one matching between the African American and white workers. Since there are fewer African American workers than white workers, samples are drawn randomly from the white sample. Fifty different samples are drawn, racial differences estimated using each sample and the mean results from across the fifty different samples reported.

\section{Va. Racial Differences in Fringe Benefits at the extensive margin}

The appendix tables A2 and A3 provide summary statistics of individual and workplace characteristics by race and gender for the samples drawn from the Current Population Surveys. The data is constructed by merging respondents from the February and March supplements of the Current Population Surveys; since the February supplements are available for specific years we have data for the 1997, 1999, 2001 and 2005 cohorts. Further, we restrict our sample to workers who are between the ages of 25 and 65 , to full-time workers who work more than 35 hours per week and who work in the private sector. These restrictions give us a sample of 51,736 white men, 4,271 African American men, 35,190 white women and 4,702 African American women.

A larger fraction of all workers are offered employer provided health insurance than pensions. The highest fraction of health insurance offers is for white men, of whom $90 \%$ get health insurance offers. $87 \%$ of the African American men get health insurance offers, while $85 \%$ of both white and African American women get health insurance offers. The highest fraction of pension offers is also for white men at $74 \%$. African American men get the lowest fraction of pension offers at $67 \%$. $71 \%$ of white women and $69 \%$ of African American women get pension offers. If one looks at groups receiving both fringe benefits, then again white men have the highest offer rates of health insurance and pensions at $71 \%$ and African American men have the lowest offer rates at $64 \%$. White women have offer rates of $66 \%$ and African American women of $64 \%$.

Summary statistics of individual characteristics of the CPS samples as given in appendix tables A2 and A3 show that the African American samples are more likely to have some high school, high school or some 
college education but that the white samples are far more likely to have college graduate or higher education. Women are slightly younger in the sample in comparison to men. There are also far more African American workers in the South than in any other region, which is consistent with the population distribution of African Americans in the US. African American women are more likely to have younger children at home, and spouse wages are far higher for white women than for African American women.

Workplace characteristics across different race and gender groups in the CPS samples show that African Americans are far more likely to be working in unionized jobs than white workers. They are also more likely to work in the largest firms (those with 1000+ workers) than are white workers. White workers are more likely to be in executive/professional and sales occupations while African American workers are more likely to be in factory labor and construction, services and transportation occupations. Women are more likely to be in administrative occupations. Across different industries, manufacturing has higher fractions of African Americans than whites, while financial and education/health services are dominated by women.

Given the CPS data, we next run the different specifications on the samples. Table 4 reports the estimation results for health insurance offers when using the CPS data for full time workers working in the private sector from the 1997, 1999, 2001 and 2005 cohorts. The cohorts are pooled together, and year dummies included in all estimations. Panel A gives the results when race dummies are included in the probit regressions and Panel B gives the results from the non-linear decompositions. In (I), estimation results are reported when we use individual level controls only which include human capital variables such as education and age, family traits variables such as children and spouse salary and also local labor market variables such as regional dummies. The set of dummy variables for education are: whether the worker has no education, some high school education, high school education or college/grad school education. We use four region dummies. According to the estimations the marginal effect of being African American on whether a person gets a health insurance offer from the employer is negative and significant at -0.0161 for men; for women the marginal effect of being African American is insignificant. In (II), estimation results are reported when workplace or firm level controls are included in addition to the individual level variables. These include union membership, ${ }^{9}$ firm size, occupation, and industry. We use five dummy variables for firm size: whether number of employees in the firm are less than 25, between 25 and 99, between 100 and 499, between 500 and 999 or greater than 1000. We use eight dummies for occupation and thirteen dummies for industry. Inclusion of workplace controls increases the marginal effect associated with being African American to almost twice its level without the firm level controls for the male samples, -0.0293 instead

\footnotetext{
${ }^{9}$ Since 1983, questions on union/employment association membership are asked only to a quarter of the sample (the outgoing rotation groups) in each month (Hirsch and Macpherson). To obtain information of union membership for the remaining three quarters of the sample in each year, we make use their responses to the Basic CPS survey in the following months. Specifically, we look at their responses to the questions on union membership during their outgoing interviews. We also restrict to those who do not experience unemployment between the ASEC and their outgoing interview. Doing so essentially eliminate those who changed jobs during this period, which will contaminate our data (i.e. the employer that offers pension may not be the employer the interviewee worked for during the month when he answered the union membership questions).
} 
of -0.0161. The increase in the marginal effect is because African American men are more likely to be in unionized and bigger firms which are the kind of firms more likely to offer fringe benefits. For women, the marginal effect of being African American is now negative but still insignificant. In the decomposition results, inclusion of the latter set of control variables changes the component of the explained difference from positive to negative. In other words, racial differences in workplace controls favor health insurance coverage for African American men and women. The unexplained differences in health insurance coverage across race, however, favors white men and women.

Table 5 gives the estimation results for pension offers with a race dummy included in the set of regressors in section A and from non-linear decompositions in section B. Table 5 uses CPS data for full time workers working in the private sector from 1997, 1999, 2001 and 2005 cohorts. In (I), estimation results are reported when individual level controls only are included. The marginal effect of being African American on getting an offer of pension coverage is significant and negative for men at -0.0354. For women the marginal effect is negative but insignificant. In (II), estimation results are reported when workplace controls are included in addition to individual level controls. Inclusion of workplace controls increases the marginal effect associated with the African American dummy on getting an offer of pension coverage to - 0.0791 from - 0.0354 for men and to - 0.0522 for women. The marginal effect of being African American is significantly negative after including workplace controls, for both the male and female sub-samples. In the decomposition results, inclusion of the workplace controls changes the component of the explained difference from positive to negative. As for health insurance, the racial differences in workplace controls favors pension offers for African American men and women. The unexplained difference in pension offers across race favors white men and women.

From the CPS data, being African American is associated with significantly lower offer rates for employer provided health insurance and employer provided pension for men. These differences are particularly large once we control for workplace characteristics since African Americans are infact more likely to be working in the kind of jobs (unionized and with larger firms) that provide these fringe benefits. The differences in fringe benefit offers are smaller for women in the CPS samples. One explanation for why we observe the racial differences for men could be associated with how African American men sort into different firms, with more of them working for employers that may be less prejudiced in hiring African Americans but who at the same time offer fewer fringe benefits. The other reason we might observe the racial differences is because of important omitted variables. In the next section, we control for an important source of omitted variable bias, which is ability difference across racial groups.

\section{Vb. Racial Differences in Fringe Benefits at the extensive margin and the role of ability}

Using the National Longitudinal Study of Youth data allows us to use a more rich set of individual level controls in our models of fringe benefit offers. In particular we are interested in how racial differences in 
ability, as proxied by the AFQT test score, have an impact on racial differences in employer provided fringe benefits such as health insurance and pensions. The role of ability in wage differentials is well documented. The mechanism through which ability differences can also play a role in fringe benefits and compensation is through the progressive nature of the tax system. High ability individuals may find it worthwhile to take a larger portion of their compensation in the form of tax exempt fringe benefits.

The appendix tables A4 and A5 provide summary statistics of individual and workplace characteristics by race and gender for the samples drawn from the National Longitudinal Survey of Youth data. The data we use is pooled from the 1996, 1998, 2000, 2002 and 2004 rounds of the NLSY data. We restrict our sample to workers who are between the ages of 25 and 65 , and to full-time workers who work more than 35 hours per week. These restrictions give us a sample of 1,607 white men, 652 African American men, 1,284 white women and 678 African American women.

A broadly similar fraction of all workers are offered fringe benefits in the NLSY data in comparison to the CPS. As many as $86 \%$ of white men get offers of health insurance, while $79 \%$ of African American men get such offers. $85 \%$ of white women and African American women get offers of health insurance. The fraction of pension offers for white men is 75\%. 68\% of African American men get pension offers. $75 \%$ of white women and $77 \%$ of African American women get pension offers. That African American women have higher offer rates of pension in the NLSY is observed also in the sub-sample of workers who work in the private sector only (see appendix table A6). White men also have the highest offer rates of both health insurance and pensions at $71 \%$ while $64 \%$ of African American men have offers of both health insurance and pensions. White women have offer rates of $66 \%$ and African American women of $64 \%$.

Summary statistics of individual characteristics of the NLSY samples show that, as in the CPS, the African American samples are more likely to have some high school, high school or some college education but that the white samples are far more likely to have college graduate or higher education. Again as in the CPS, there are far more African American workers in the South than in any other region, which is consistent with the population distribution of African Americans in the US. African American women are the most likely to have younger children at home, and spouse wages are far higher for white women than for African American women. Finally, the AFQT scores (standardized by age) are very different across African Americans and whites, with the mean score being positive for whites and negative for African Americans.

Workplace characteristics across different race and gender groups in the NLSY samples show that African Americans are more likely to be working in unionized jobs than white workers. They are also more likely to work in the largest firms than are white workers. Both of these are again consistent with CPS data. White workers are more likely to be in Professional, Technical and Managerial occupations while African American workers are more likely to be in clerical, operatives and service occupations.

Table 6 gives the estimation results from probit regressions on health insurance offers with a race dummy 
in section A and from non-linear decompositions in section B. We use data for full time workers from 1996 to 2006 rounds of the NLSY, the data being pooled with year dummies included in the estimations. In (I), estimation results are reported when we use individual level controls such as education, age, region, children, and spouse salary in the regressions. In (II) estimation results are reported with the addition of the AFQT test score, standardized by age. In (III), estimation results are reported when we include workplace controls such as union membership, firm size, occupation, industry and work type but exclude AFQT. In (IV) we again add standardized AFQT scores to the set of regressors. With the addition of AFQT test scores the marginal effect associated with being African American is dramatically reduced and becomes insignificant. For women the marginal effect associated with being African American is not significant without AFQT but with the addition of AFQT it is significant and positive. This can also be seen in the non-linear decompositions; inclusion of the AFQT score for men reduces the difference between rows (6) and (7), which is the difference in health insurance offer rates favoring white men and not explained by differences in characteristics. For women, inclusion of AFQT score increases the difference between rows (6) and (7), which is the difference in health insurance offer rates favoring African American women and not explained by differences in characteristics.

Table 7 gives the estimation results from probit regressions on pension offers with a race dummy in section A and from non-linear decompositions in section B. Table 7 use NLSY79 data for full time workers from 1996 to 2006 rounds, the data being pooled with year dummies included in the estimation. (I) gives the estimation results when individual level controls such as education, age, region, children, and spouse salary are used as the control variables. In (II) estimation results are reported with inclusion of the AFQT test score, standardized by age. In (III), estimation results are reported when we include workplace controls such as union membership, firm size, occupation, industry and work type but exclude AFQT. In (IV) we again add standardized AFQT scores to the set of regressors. The marginal effect associated with being African American becomes insignificant when we include AFQT scores for men. For women the marginal effect associated with being African American is positive and increases dramatically when we include AFQT test scores. This can also be seen in the non-linear decompositions; inclusion of the AFQT score for men reduces the difference between rows (6) and (7), which is the difference in pension offers not explained by differences in characteristics. For women, inclusion of AFQT increases the difference between rows (6) and (7) which is the difference in pension offers favoring African American women.

As a further robustness check, we also carry out the above analysis on samples restricted further to workers in the private sector only. The appendix tables A6 and A7 provide summary statistics of individual and workplace characteristics by race and gender for the restricted samples. The restricted sample consists of 1,240 white men, 476 African American men, 811 white women and 397 African American women.

Table 8 gives the estimation results from probit regressions on health insurance offers with a race dummy 
in section $\mathrm{A}$ and from non-linear decompositions in section $\mathrm{B}$ for the restricted sample. With the addition of AFQT test scores the marginal effect of being African American for men again declines. For women the marginal effect of being African American becomes positive and significant after inclusion of AFQT scores, as with the full sample. The results from the non-linear decompositions are also consistent with the results we get from the full sample.

Table 9 gives the estimation results from probit regressions on pension offers with a race dummy in section A and from non-linear decompositions in section B using the restricted sample. The results are entirely consistent with what we observe in the full sample; the marginal effect associated with being African American is reduced considerably after inclusion of AFQT scores for men. For women, the marginal effect is positive and significant and increases when we include AFQT scores to the set of regressors. Finally, this is also reflected in the non-linear decompositions, the unexplained difference in pension offers is reduced when we include AFQT scores for men, and the unexplained difference favoring African American women increases when we include AFQT scores for women.

As mentioned already, the CPS is a nationally representative sample while the NLSY is not; our results from the two samples are broadly consistent but there are also some important differences. The biggest difference in the NLSY data is in pension offers for women, in particular pension offers for African American women in the NLSY are far higher than in the CPS.

An important finding is the role of ability differences in fringe benefit offers. We find that once we control for ability differences much of the racial differences in fringe benefit offers disappear for men. For women, controlling for ability actually makes the race dummy positive and significant; in other words, controlling for ability differences, African American women are more likely to get fringe benefits than white women. We have no simple explanation for why this is the case, but we leave this as a question to address for future work. We next turn to measure of overall compensation and racial differences in compensation.

\section{Racial Differences in Compensation}

We define total compensation as the combined value of wages, health insurance and pension. While both the NLSY and the CPS ASEC ask about the magnitude of the wage the individual gets, the values of health insurance and pension are not asked. A plausible reason is that they are extremely difficult to measure from the perspective of the employee. The value of employer provided health insurance depends on the individual's health status, the nature of the plan, and the coverage particulars. Similarly, the value of pension to the employee depends on the current and future interest rates, the individual's assessment of future inflation, the self assessed probability of death before retirement etc. From the perspective of the employer, however, the values of these non-wage compensation items are not simple to assess either. Provision of such non wage 
compensation may improve the productivity of employees and increase the retention rates, which are both beneficial to the employer, making the value of non-wage compensation depend on more than just the costs involved in providing them.

To abstract from the complexity in modeling the value of non wage compensation, we assume their values are just the direct costs to provide them. In the CPS ASEC, individuals who are covered by employerprovided health insurance are also asked about the amount of contribution of the employer. Since the CPS asks about the dollar amount of health insurance premium contributed by the employer, we estimate a regression of these dollar amount on age, gender, occupations, industries, regions, unionization, years, nature of the plan (single or family) and number of employees in the place of work. We use the resulting estimates to impute the employer's contribution of health insurance premium for those who are offered but not covered. For pension, however, the CPS ASEC does not ask about the amount of employer's contribution. To estimate the amount paid by the employer, we use the Survey of Consumer Finances (SCF) which ask about the amount of employer's contribution towards the employee's pension (as a percent of the employee's wage). 10 We then apply these contribution rates to the CPS data and estimate the employer's contribution. Our wage data come from the March CPS; one possible concern with the use of this data is it is not a point in time measure, rather it is retrospective so that hourly wages need to be computed by dividing annual earnings by the product of weeks worked last year and usual weekly hours last year.

For NLSY, the issues involved in imputing values of non wage compensation schemes are more complicated. First, as we discussed previously, the NLSY asks whether the individual's employer makes a certain type of non-wage compensation available to him, rather than whether the individual is covered by such compensation. Second, for health insurance, we do not know the amount paid by the employer as well as the type of health insurance (such as whether it is a single or family plan). Thus we assume that in the NLSY, individuals who are offered non-wage compensation schemes always accept them. To impute the value of employer-provided pension, we again use the contribution rates estimated using the SCFs. For health insurance, we again use the CPS ASEC to estimate the amount paid by the employer based on the individual's demographic and occupational characteristics (see footnote above).

\section{VIa. Racial Differences in Compensation over time}

If we examine the total change in wages, non-wage compensation and compensation measures over the 19972005 time period (as given in figure 1), we find that wages increased across the distribution for men and women during 1997-2005, but that there was a decline in non-wage compensation in the lower percentiles for both men and women over this time period, so that the change in compensation was slightly smaller

\footnotetext{
${ }^{10}$ The SCF is a triennial cross-sectional survey containing detail data about the interviewees' income, assets and investment portfolios. We use the 1995, 1998, 2001, and 2004 SCF to estimate the average pension contribution rates (employers). We use the averages of the 1995 and 1998 rates, 1998 and 2001 rates, 2001 and 2004 rates as the rates in 1996-1997, 1999-2000, and 2002-2003 respectively.
} 
than the change in wages.

In order to examine the racial inequality in compensation we also estimate and examine three different measures of within group inequality: the overall inequality as given by the 90/10 log differential in compensation for the different years for which we have data on fringe benefit offers, the residual inequality as given by 90/10 log differential in compensation after we control for age and education and the upper and lower tail inequality as given by 90/50 and 50/10 log differentials in compensation. We use the CPS data for full-time workers working in the private sector who are between the ages of 25 and 65 .

Figure 2 gives the 90/10 log differential in compensation and the residual 90/10 log differential in compensation separately for African American and white men. From figure 2, the 90/10 inequality measure has increased for wages, for non-wage compensation and for compensation for both whites and African Americans. However, the 90/10 inequality in wages and compensation is higher among whites while the 90/10 inequality in non-wage compensation is higher among African Americans. If we look at the residual 90/10 inequality which controls for age and education, then the 90/10 inequality measures in wages and compensation are not very different among whites and among African Americans, but there is still higher inequality in non-wage compensation among African American men than white men.

Figure 3 gives the 90/10 log differential in compensation and the residual 90/10 log differential in compensation among African American and white women. Very generally, the trends we observe are similar to those for men, with the inequality measures increasing over the time period, the inequality in wages and compensation being fairly similar among African American and white women but the inequality in non-wage compensation being higher among African American women than among white women.

It is also useful to understand how the compensation inequality measures vary across African Americans and whites when we examine upper and lower tail inequality as given by the 90/50 and 50/10 inequality measures. Figure 4 gives these upper and lower tail inequality measures for male samples of the CPS. Upper tail inequality is increasing over the time period, the upper tail inequality in wages and compensation is not very different among African Americans and whites but the upper tail inequality in non-wage compensation is higher among African Americans than whites. Lower tail inequality in wages and compensation has not changed over time, in particular for white men. For African American men, lower tail inequality in both wages and in compensation dips initially but increases in 2005. Lower tail inequality in non-wage compensation is higher among African American men than among whites and has increased over time.

The upper and lower tail inequality for the female samples of the CPS is given in figure 5. For the female samples, the upper tail inequality as given by the 90/50 inequality measure has slightly increased for wages and for compensation. It remains constant for non-wage compensation. Upper tail inequality for wages, non-wage compensation and compensation is higher among African American women than among white women. Lower tail inequality in wages and compensation is constant over time but lower tail inequality in 
non-wage compensation increases and is higher among African American women than among white women.

Our findings are broadly consistent with the existing literature on inequality differences over time (for instance in Autor, Katz and Kearney [3] [4]). We find, in addition, that non-wage compensation inequality is greater among African Americans than among whites and that the dispersion in non-wage compensation and compensation is also greater among African Americans than whites over the last decade. This again highlights the importance of examining fringe benefits and compensation to get a better understanding of the extent of racial inequalities in the labor market.

\section{VIb. Racial Differences in Compensation and the role of ability}

We also examine how unexplained differences in total compensation across racial groups are affected by inclusion of AFQT test scores using NLSY data. We do this by carrying out quantile decompositions of total compensation, with and without including AFQT in the set of characteristics (other characteristics include education, tenure and the square of tenure). While the Oaxaca-Blinder and non-linear decompositions given in equations 1 and 2 estimate the average treatment effect on the treated by using linear/non-linear regressions (the first parts of equations 3 and 4 or the explained difference across groups), quantile decompositions extend the method to quantiles by using linear quantile regressions (see Melly[29]). These allow us to examine the unexplained differences across racial groups at different points of the distribution of wages, non-wage compensation and of total compensation; in this way we are also able to examine if ability differences play a role in non-wage compensation at the intensive margin.

In order to examine the role of ability in racial differences in compensation, we first pool the NLSY data from 1996 to 2006 for all full time workers between the ages of 25 and 65 and estimate the unexplained differences (unexplained after controlling for education, age and a quadratic in age). 95\% confidence intervals are estimated around the unexplained difference using 100 bootstrap replications. Figure 6 gives the estimation results for men and 7 gives the estimation results for women. The figures superimpose the unexplained differences with and without inclusion of standardized AFQT scores for easy reference. It is clear from the pooled male samples that inclusion of standardized AFQT scores reduces the unexplained difference in wages (this is already well documented) and also in non-wage compensation (at the intensive margin so conditional on getting fringe benefits, ability differences also play a role in the amount that is received in the form on non-wage compensation) and compensation at all points of the distribution. The difference is fairly large so that the $95 \%$ confidence intervals for the two cases do not overlap. For the pooled female samples also, we find that inclusion of standardized AFQT scores reduces unexplained differences in wages, non-wage compensation and compensation. However, unlike for men, the difference in non-wage compensation is not very large, there is considerable overlap in the confidence regions of the unexplained difference estimated with and without including AFQT test scores. 
We also examine the role of ability differences when we restrict the NLSY sample further to workers who work only in the private sector. The resulting unexplained differences across racial groups are given in figure 8 for men and figure 9 for women. As in the full sample, there is a reduction in unexplained differences after including standardized AFQT scores across the entire distributions of wages, non-wage compensation and compensation, and in addition there is also little overlap in the $95 \%$ confidence intervals across the unexplained difference.

\section{Caveats and Directions for Future Work}

Several caveats are in order. First, our assumption that by focusing only on those who are employed full-time and work over 35 hours per week, we eliminate all those who are not taking up Health Insurance because of exogenous reasons. It is however plausible that those who know that they cannot take up employer-provided health insurance due to exogenous reasons may instead report that non-takeup is a personal choice. If this happens, the offer rate overstates the recipiency of these fringe benefits. More seriously, if this behavior differs across race and gender groups, then our results may be invalid. This issue is not easy to resolve as one would need to find out whether those who reject employer-provided health insurance due to personal decision are actually ineligible for such benefit.

Second, our empirical strategy has made a large number of simplifications. In the case of imputing the value of an employer-provided pension plan, our strategy is somewhat over-simplified due to data limitations. In future revisions of this paper, we hope to devise a more sophisticated method of calculating the value of a pension plan, if we have better data.

Third, we have utilized only the employer-cost of fringe benefits rather than their values in analyzing racial difference in total compensation. In the case of employer-provided health insurance, it is likely that those with bad health would value such benefit much higher than the cost (because they have difficulties to purchase the insurance privately due to their risks). If there is a significant difference in health status across the racial groups, it may be viable to derive a measure of the personal value of total compensation rather than just its monetary value. There is some medical literature that suggests that African Americans are likely to be in worse health than whites, thus the value of employer provided health insurance to African Americans may actually be higher.

Fourth, there are other fringe benefits that we hope to incorporate in our paper, such as life insurance.

Fifth, we can also study total compensation inequality for those in the lower section of the income distribution (or those with less education). Such an analysis may capture a somewhat different picture compared with that of using wages alone. It will also be interesting to see how the inclusion of the value of fringe benefits affects the poverty rates. 


\section{Conclusion}

We find that white men have significantly higher employer-provided health insurance and pension coverage than do African American men. Of the unexplained racial differences that favor white men, a large component disappears when we control for racial differences in ability. The racial differences for women are smaller than for men in fringe benefit recepiency, for both health insurance and pensions. Once we control for racial differences in ability, we find that African American women are actually more likely to receive fringe benefits than are white women.

We also construct total compensation measures and examine within-group inequality in compensation over time as well as the role of ability differences in between-group compensation inequality. We find that non-wage compensation inequality is greater among African Americans than among whites and that the dispersion in non-wage compensation and compensation is also greater among African Americans than whites over the last decade. In addition, we find that ability differences reduce the unexplained racial differences in compensation for men and women across the compensation distribution. This again highlights the importance of racial differences in ability in fringe benefits and compensation, at the intensive as well as extensive margins.

Several questions remain unanswered. For instance, it is not clear what causes racial differences in nonwage compensation to be so different for men and women. Our study also suggests a number of ideas for future research. Given the increasing interest in the Hispanics population, one can also explore more about the racial inequality between Hispanics and whites. Second, our investigation of take-up behavior suggests a substantial number of individuals are not taking-up employer provided health insurance for personal reasons such as not believing health insurance and do not like the plan. With longitudinal data, one can investigate the long-term health well-being of these individuals as well as for their family members. With firm level data, one can also investigate the characteristics of health insurance plans that make employees not to take up. Future studies should look at a greater variety of non-wage compensation benefits provided to employees in addition to health insurance and pensions. A better understanding of the differences in non-wage compensation across racial groups is important in proper measurement of the extent of racial inequalities in labor markets. 


\section{References}

[1] Altonji, Joseph G. and Rebecca Blank (1999), 'Race and Gender in the Labor Market', in: O. Ashenfelter and D. Card eds. Handbook of Labor Economics, Vol 3, Elsevier Science B.V.

[2] Anderson, Patricia M. and Bruce Meyer (1997), 'Unemployment Insurance Takeup Rates and the AfterTax Value of Benefits,' Quarterly Journal of Economics, CXII, 913-938.

[3] Autor, David H, Lawrence F Katz and Melissa Kearney (2006), 'The Polarization of the U.S. Labor Market,' American Economic Review Papers and Proceedings, 96(2), 189-194.

[4] Autor, David H, Lawrence F Katz and Melissa Kearney (2008), 'Trends in U.S. Wage Inequality: Revising the Revisionists,' Review of Economics and Statistics.

[5] Bloom, David E and Richard B Freeman (1992) 'The Fall in Private Pension Coverage in the United States,' American Economic Review, LXXXII, 539-545.

[6] Charles, Kerwin Kofi and Jonathan Guryan (2007) 'Prejudice and The Economics of Discrimination,' NBER Working Papers 13661.

[7] Chung, Wankyo (2003) 'Fringe Benefits and Inequality in the Labor Market,' Economic Inquiry 41(3): 517529.

[8] Currie, Janet (1997), 'Gender Gaps in Benefits Coverage,' in The Handbook of Human Resource Management, David Lewin, Daniel Mitchell and Mahmood Zaidi (eds), JAI Press, 1997, 175-198.

[9] Currie, Janet and Brigitte Madrian (1999), 'Health, Health Insurance and the Labor Market,' The Handbook of Labor Economics, volume 3c, David Card and Orley Ashenfelter (eds.), Amsterdam: North Holland, 1999, 3309-3407.

[10] Currie, Janet and Aaron Yelowitz (2000), 'Health Insurance and Less Skilled Workers,' in Finding Jobs: Work and Welfare Reform, David Card and Rebecca Blank (eds.), New York: Russell Sage, 233-261.

[11] Cutler, David M and Brigitte C Madrian (1998), 'Labor Market Responses to Rising Health Insurance Costs: Evidence on Hours Worked,' Rand Joural of Economics, XXIX, 509-530.

[12] Duncan, Gregory (1976), 'Earnings Functions and Nonpecuniary Benefits,' Journal of Human Resources, 11(4): 462-483.

[13] Dushi, Irena and Marjorie Honig (2005) 'Offers or Take-Up: Explaining Minorities Lower Health Insurance Coverage,' Economic Research Initiative on the Uninsured Working Paper 40; http://www.umich.edu/ eriu/pdf/wp40.pdf. 
[14] Even, William E. and David A. Macpherson (1990), 'The Gender Gap in Pensions and Wages,' Review of Economics and Statistics, 72(2): 259-265.

[15] Even, William E. and David A. Macpherson (1994), 'Gender Differences in Pensions,' Journal of Human Resources 29 (2): 555-587.

[16] Fairlie, Robert (2005), 'An Extension of the Blinder-Oaxaca Decomposition Technique to Logit and Probit Models,' Journal of Economics and Social Measurement, 30(4): 305-316.

[17] Fairlie, Robert and Rebecca London (2008), 'Who is at Risk of Losing and Gaining Health Insurance,' forthcoming in Industrial Relations.

[18] Farber, Henry S and Helen Levy (2000), 'Recent Trends in Employer-Sponsored Health Insurance Coverage: Are Bad Jobs getting worse,' Journal of Health Economics, XIX, 93-119.

[19] Hamermesh, Daniel S. (1999), 'Changing Inequality in Markets for Workplace Amenities,' Quarterly Journal of Economics, CXIV, 1085-1123.

[20] Herrnstein, Richard, and Charles Murray (1994), 'The Bell curve: Intelligence and Class Structure in American Life,' New York: Free Press.

[21] Hirsch, Barry T. and David A. Macpherson (2003), 'Union Membership and Coverage Database from the Current Population Survey: Note,' Industrial and Labor Relations Review, Vol. 56, No. 2, January 2003, pp. 349-54.

[22] Hirsch, Barry T and David A. Macpherson (2004) 'Wages, Sorting on Skill, and the Racial Composition of Jobs,' Journal of Labor Economics, University of Chicago Press, vol. 22(1), pages 189-210, January.

[23] Hu, Luojia and Christopher Taber (2005), 'Layoffs, Lemons, Race and Gender,' IZA Discussion Paper 1702.

[24] Juhn, Chinhui, Kevin Murphy and Brooks Pierce (1993) 'Wage Inequality and the Rise in Returns to Skill,' Journal of Political Economy, University of Chicago Press, vol. 101(3), pages 410-42.

[25] Kaiser Family Foundation. 2009. 'Health care Costs, A Primer.' The Henry J. Kaiser Family Foundation, Menlo Park, CA

[26] Kaiser Family Foundation and Health Research and Educational Trust. 2008. 'Employer Health Benefits - 2008 Annual Survey.' The Henry J. Kaiser Family Foundation, Menlo Park, CA.

[27] Levy, Helen (2006), 'Health Insurance and the Wage Gap,' NBER Working Paper 11975. 
[28] Machado, Jose and Jose Mata (2005), 'Counterfactual Decompositions of Changes in Wage Distributions using Quantile Regression.' Journal of Applied Econometrics, 20(4), 445-65.

[29] Melly, Blaise (2006), 'Estimation of counterfactual distributions using quantile regression,' mimeo.

[30] Monheit A and J Vistnes (2000) 'Race/Ethnicity and Health Insurance Status: 1987 and 1996,' Medical Care Research and Review. 57(Supplement 1): 11-35.

[31] Neal, Derek (2004), 'The Measured Black-White Wage Gap among Women is too Small,' Journal of Political Economy, 112.

[32] Neal, Derek (2006) 'Why Has Black-White Skill Convergence Stopped?' Handbook of Economics of Education, edited by Eric Hanushek and Finis Welch, Elsiver. (NBER Working paper 11090)

[33] Neal, Derek A and William R Johnson (1996) 'The Role of Premarket Factors in Black-White Wage Differences,' Journal of Political Economy, University of Chicago Press, vol. 104(5), pages 869-95, October.

[34] Oaxaca, Ronald,'Male-Female Wage Differentials in Urban Labor Markets,' International Economic Review 14: 693-709.

[35] Pierce, Brooke (2001), 'Compensation Inequality,' Quarterly Journal of Economics 116(4): 1493-1525.

[36] Royalty, Anne Beeson (2000), 'Tax Preferences for Employee Benefits and Workers Eligibility for Employer Health Insurance,' Journal of Public Economics, LXXV, 209-227.

[37] Schiller, Bradley R. and Randall D. Wise (1980), 'The Impact of Private Pensions on Firm Attachments,' 61: 369-380.

[38] Solberg, Eric and Teresa Laughlin (1995), 'The Gender Pay Gap, Fringe Benefits, and Occupational Crowding,' Industrial and Labor Relations Review, 48(4): 692-708.

[39] U.S. Department of Labor. Various Years. 'Employer Costs for Employee Compensation - March.'

[40] Woodbury, Stephen A (1983), 'Substitution between Wage and Nonwage Benefits,' American Economic Review, 73(1): 166-182 


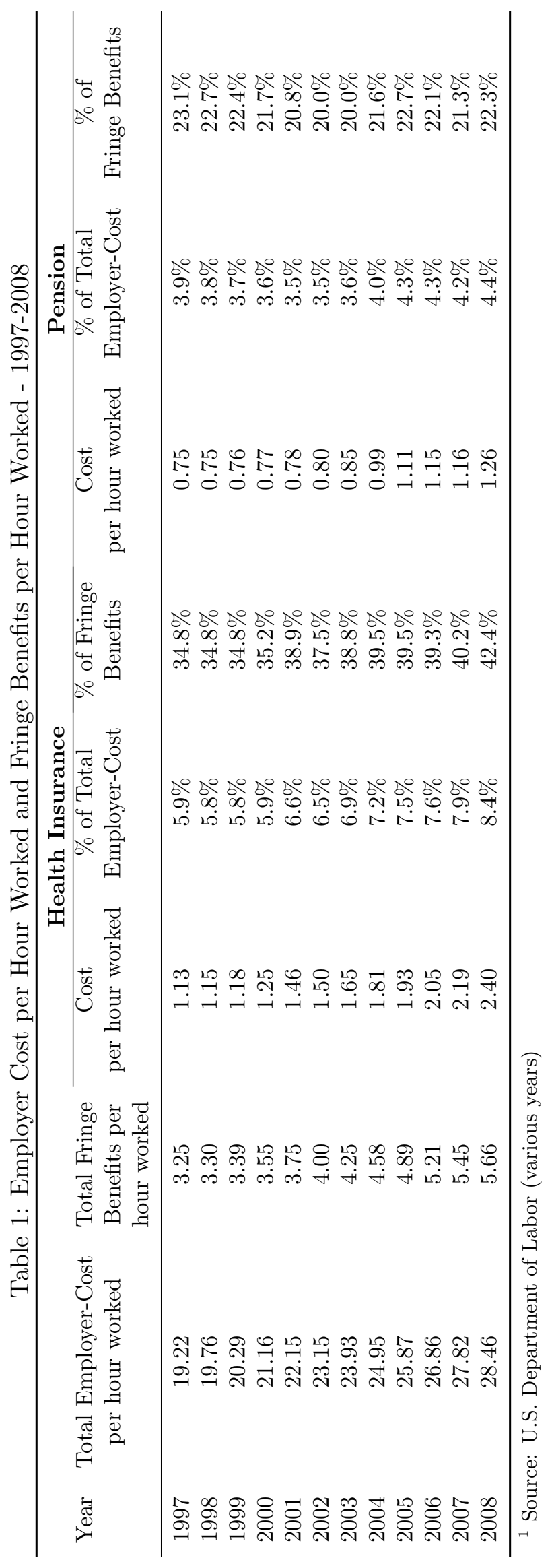


Table 2: Employer-Provided Health Insurance Take-Up Rates, and Reasons for Not Taking Up, by race and gender

\begin{tabular}{|c|c|c|c|c|c|c|}
\hline \multirow{4}{*}{$\begin{array}{l}\text { SIPP } \\
\text { Panel }\end{array}$} & & \multicolumn{5}{|c|}{ Reasons for Not Taking Up Employer HI (Among Those Not Taking Up) } \\
\hline & & Ineligible due & Denied by the & & & Personal \\
\hline & & to type of & Insurance & Covered by & Too & Reasons other \\
\hline & & employment & Company & Other Plans & Expensive & than cost \\
\hline \multirow{4}{*}{1996} & White-Male & 0.291 & 0.012 & 0.355 & 0.164 & 0.084 \\
\hline & White-Female & 0.300 & 0.013 & 0.461 & 0.112 & 0.059 \\
\hline & Black-Male & 0.370 & 0.003 & 0.242 & 0.199 & 0.079 \\
\hline & Black-Female & 0.362 & 0.014 & 0.302 & 0.153 & 0.050 \\
\hline \multirow[t]{4}{*}{2001} & White-Male & 0.244 & 0.012 & 0.375 & 0.160 & 0.069 \\
\hline & White-Female & 0.265 & 0.007 & 0.471 & 0.099 & 0.046 \\
\hline & Black-Male & 0.223 & 0.006 & 0.332 & 0.179 & 0.095 \\
\hline & Black-Female & 0.305 & 0.016 & 0.287 & 0.217 & 0.058 \\
\hline
\end{tabular}

\footnotetext{
${ }^{1}$ Data come from the wave 5 topical modules of the 1996 and 2001 SIPP panels.

${ }^{2}$ The sample is restricted to those who are currently working in private companies and those who are 22-64 years of age.

${ }^{3}$ Column 1 shows the percentage of workers who are offered health insurance by their employers. Column 2 shows the percentage of workers who are covered by employer-provided health insurance. Columns 3-7 show the percentages of those who are not taking up employer provided health insurance due to various reasons (individuals may elect more than one reason for not taking up).
}

Table 3: CPS Health Insurance and Pension Plans Offer Rates

\section{A. Health Insurance Plans}

\begin{tabular}{|c|c|c|c|c|c|}
\hline \multirow[b]{2}{*}{ Year } & All & \multicolumn{2}{|c|}{ Men } & \multicolumn{2}{|c|}{ Women } \\
\hline & HI Offered & White & Black & White & Black \\
\hline 1997 & 0.8782 & 0.8895 & 0.8462 & 0.8678 & 0.8571 \\
\hline 1999 & 0.8759 & 0.8914 & 0.8568 & 0.8577 & 0.8537 \\
\hline 2001 & 0.8802 & 0.8878 & 0.8620 & 0.8725 & 0.8716 \\
\hline 2005 & 0.8660 & 0.8722 & 0.8280 & 0.8625 & 0.8561 \\
\hline \multicolumn{6}{|c|}{ B. Pension Plans } \\
\hline & All & & & & \\
\hline Year & P Offered & White & Black & White & Black \\
\hline 1997 & 0.6963 & 0.7028 & 0.6492 & 0.6976 & 0.6551 \\
\hline 1999 & 0.7094 & 0.7224 & 0.6836 & 0.6986 & 0.6670 \\
\hline 2001 & 0.7043 & 0.7103 & 0.6285 & 0.7119 & 0.6583 \\
\hline 2005 & 0.6850 & 0.6880 & 0.6231 & 0.6896 & 0.6691 \\
\hline
\end{tabular}

${ }^{1}$ Data come from the CPS February Supplements and CPS Annual Demographic Files/Annual Social and Economic Supplements.

${ }^{2}$ We restrict the sample to those 25-64 years old who work above 35 hours a week in the private sector. 
Table 4: Racial differences in health insurance, CPS data

Male Sample

Female Sample

(I)

(II)

(I)

Controls:

(1) Education, age, region, children, spouse

Yes Yes Yes Yes
salary

(2) Add union membership, firm size, occupa-

No

Yes

No

Yes tion, industry
(A) Combined sample with race dummies

(3) Black marginal effect

$\begin{array}{cccc}-0.0161^{* * *} & -0.0293^{* * *} & 0.0043 & -0.0164 \\ (0.0064) & (0.0062) & (0.0088) & (0.0091)\end{array}$

(B) Non-linear decompositions

$\begin{array}{lllll}\text { (4) Total difference } & 0.0301 & 0.0301 & 0.0025 & 0.0025\end{array}$

(5) Explained by characteristics

0.0125

$-0.0001$

$0.0081 \quad-0.0094$

${ }^{1}$ Combined dataset from 1995, 1997, 1999 and 2005 CPS cohorts, full time workers in private sector only.

2 In all regressions and decompositions, year dummies are included.

${ }^{3}$ Standard errors in parentheses.

Table 5: Racial differences in pensions, CPS data

\section{Male Sample}

Female Sample

(I)

(II)

(I)

(II)

\section{Controls:}

(1) Education, age, region, children, spouse salary

(2) Add union membership, firm size, occupa-

Yes

Yes

Yes

Yes tion, industry

No

Yes

No

Yes

(A) Combined sample with race dummies

(3) Black marginal effect

$\begin{array}{cccc}-0.0354^{* * *} & -0.0791^{* * *} & -0.0020 & -0.0522^{* * *} \\ (0.0098) & (0.0107) & (0.0117) & (0.0130)\end{array}$

(B) Non-linear decompositions

(4) Total difference
(5) Explained by characteristics

0.0609

0.0609

0.0182

0.0182

${ }^{1}$ Combined dataset fom 1995, 1997, 14

0.0263

$-0.0048$

0.0176

$-0.0226$

\footnotetext{
${ }^{1}$ Combined dataset from 1995, 1997, 1999 and 2005 CPS cohorts, full time workers in private sector only.

${ }^{2}$ In all regressions and decompositions, year dummies are included.

3 Standard errors in parentheses.
} 


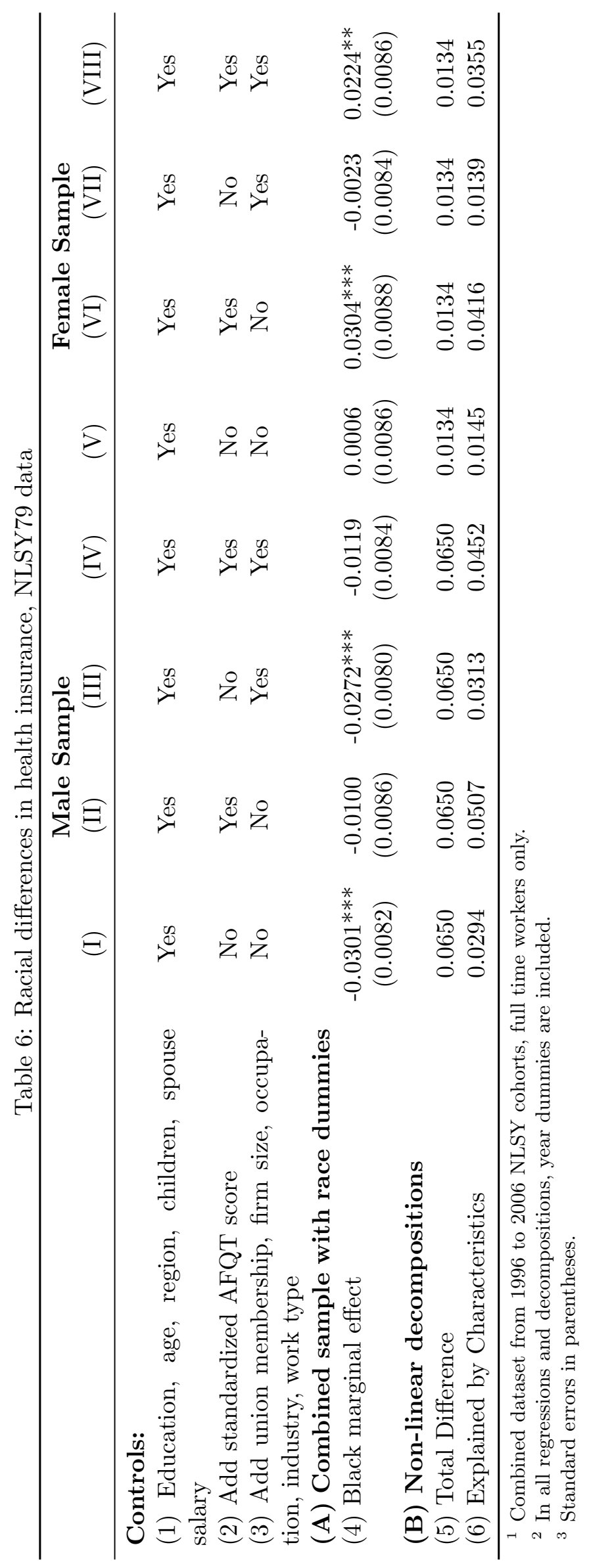




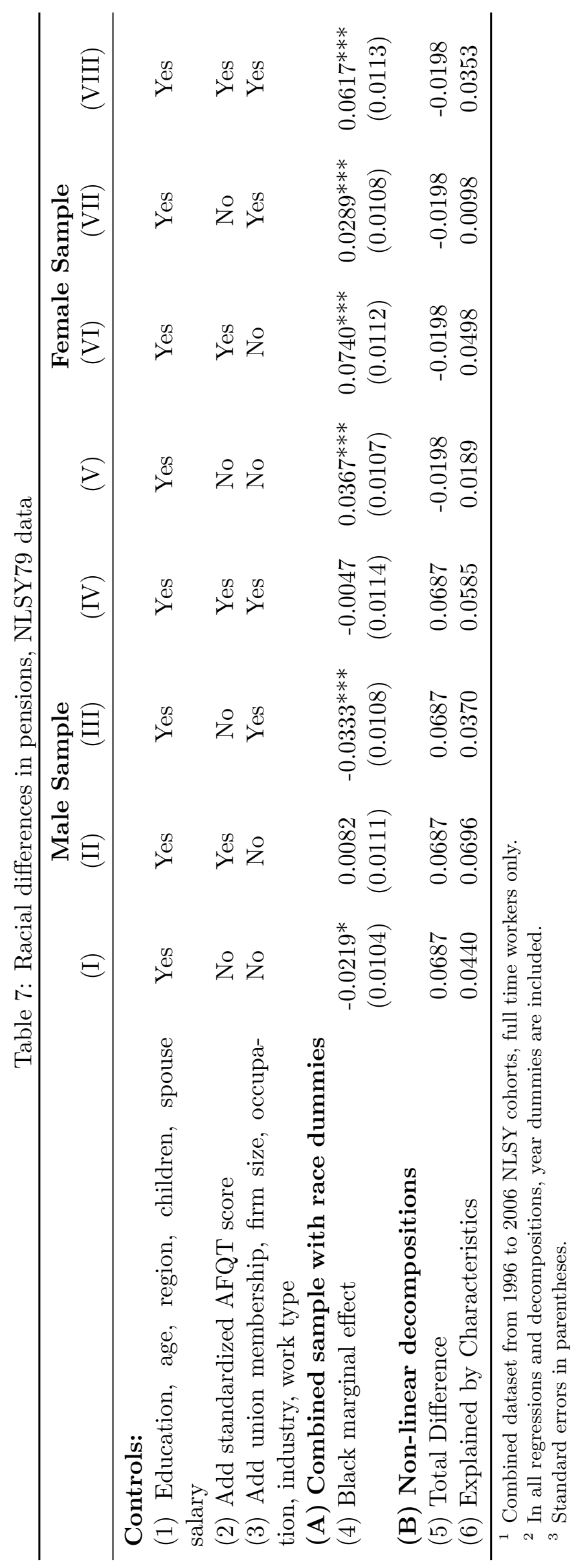




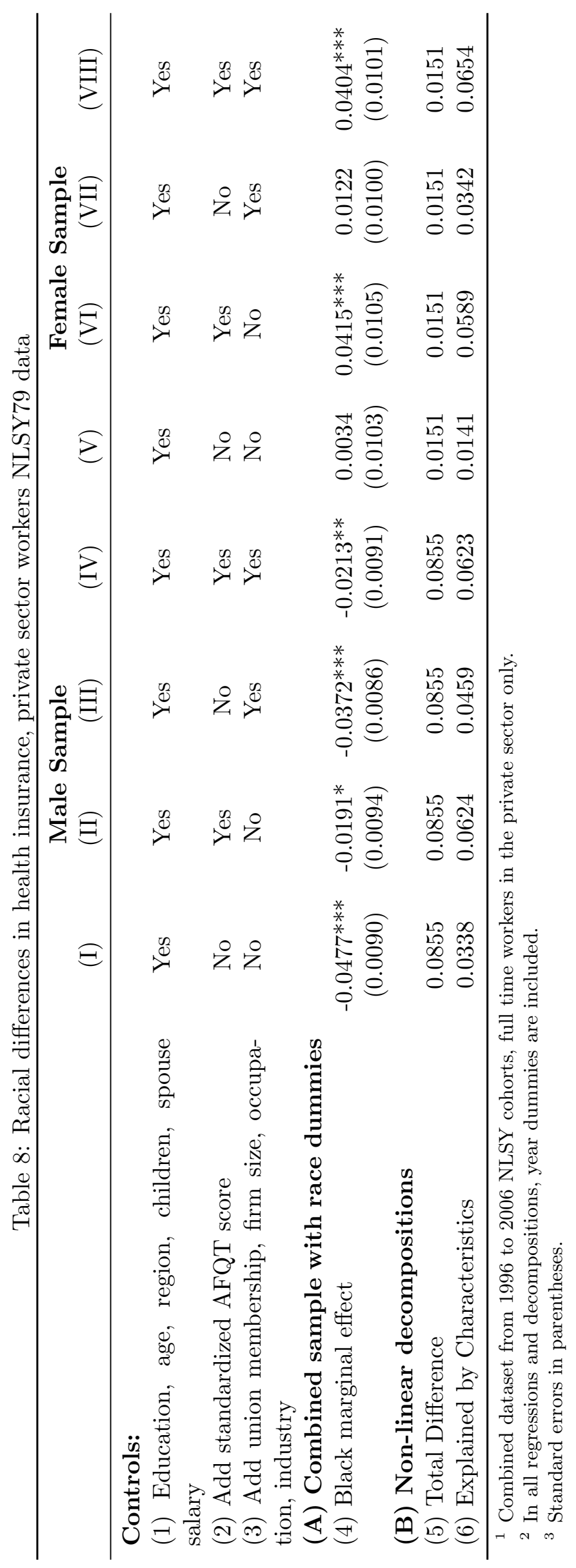




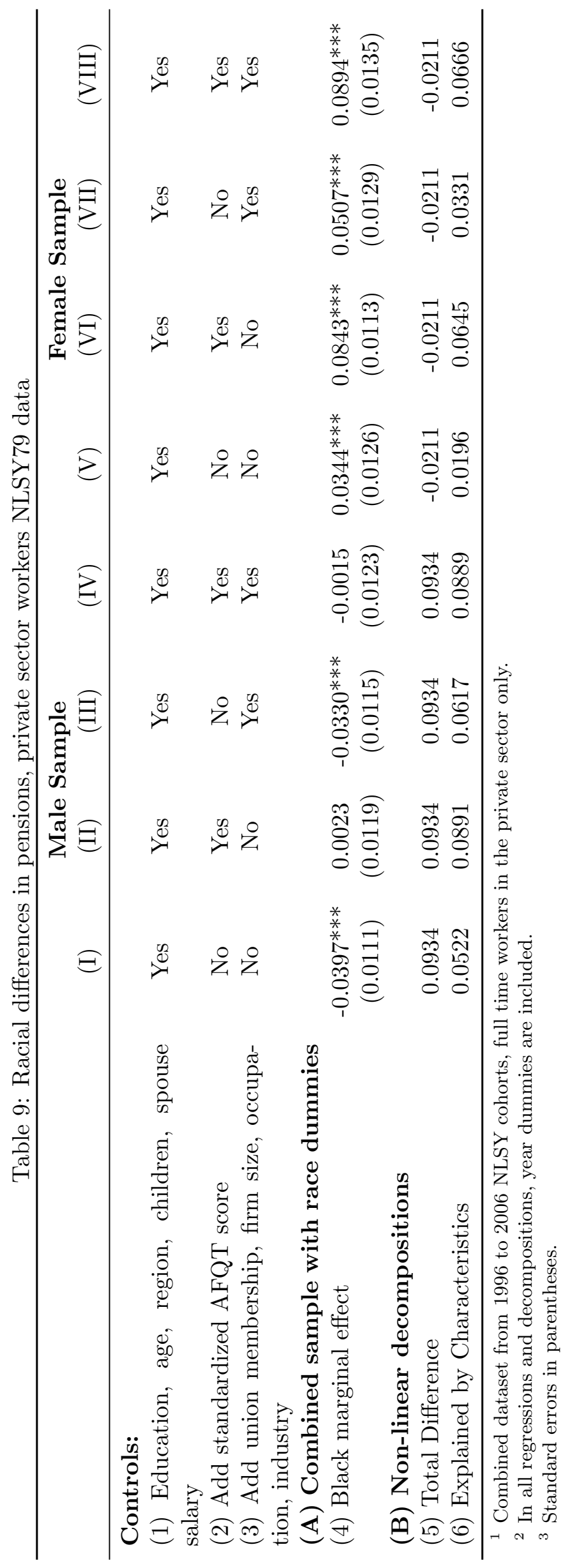




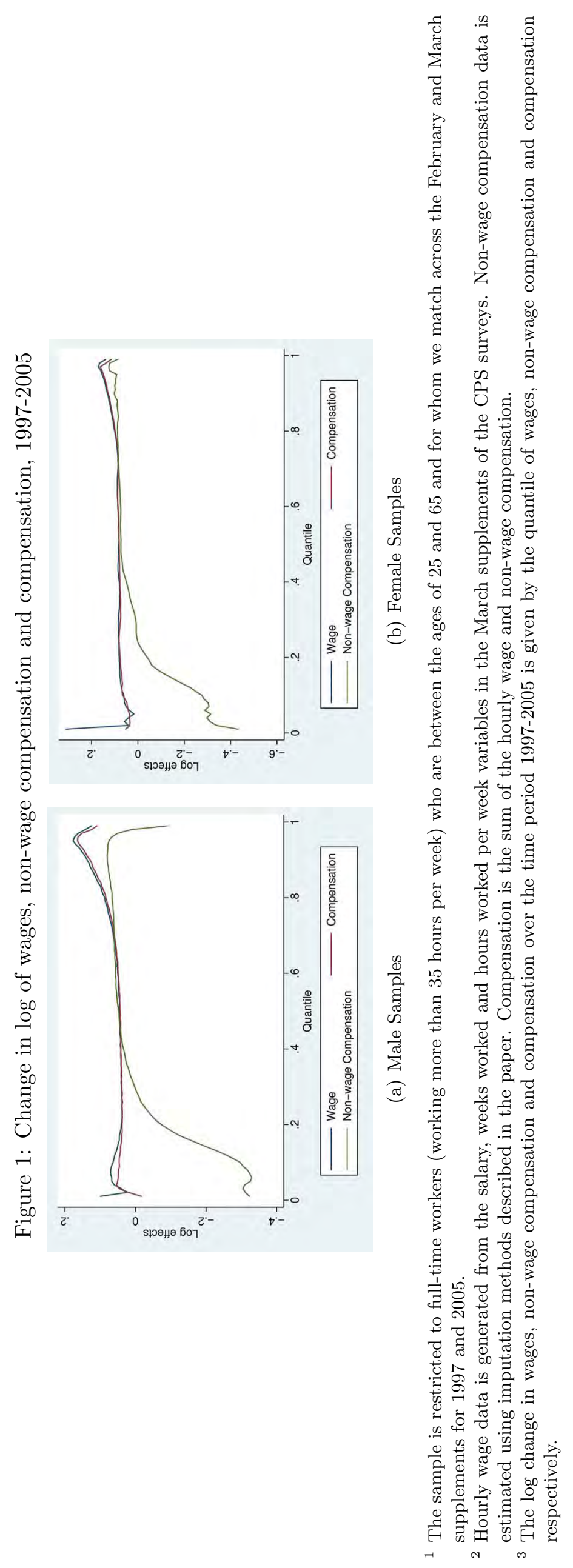




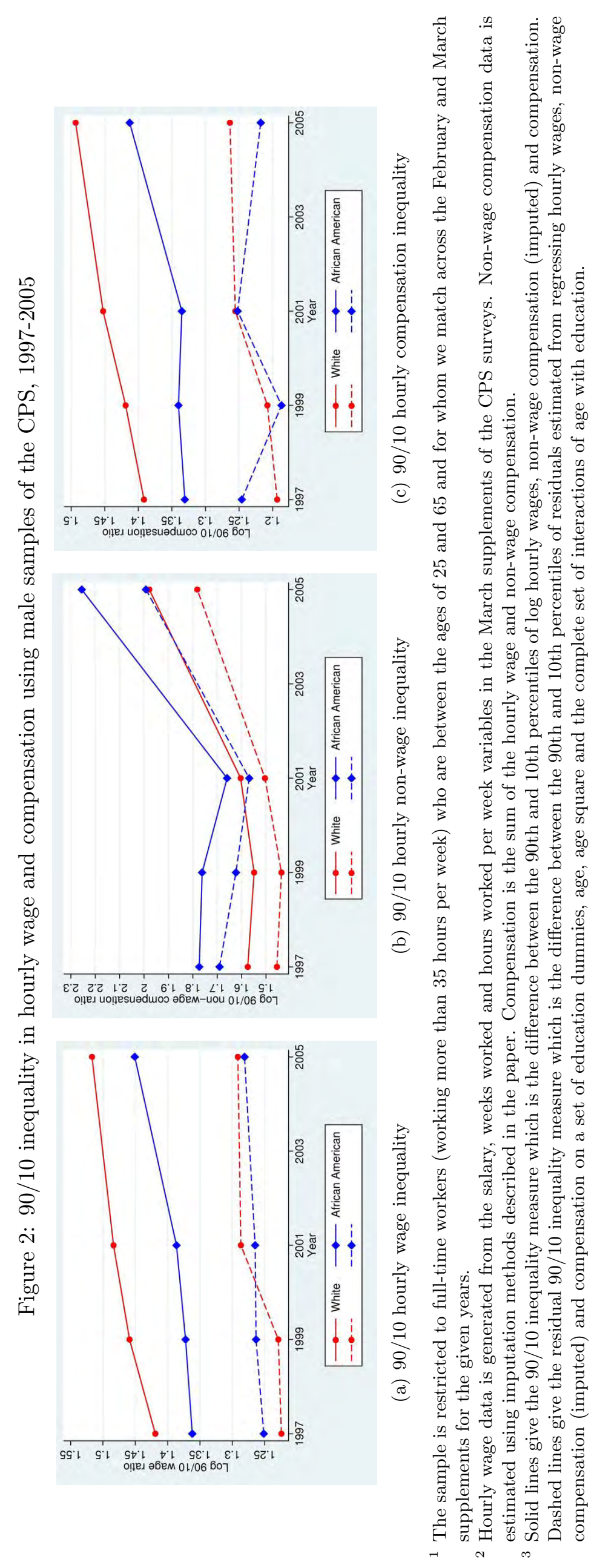




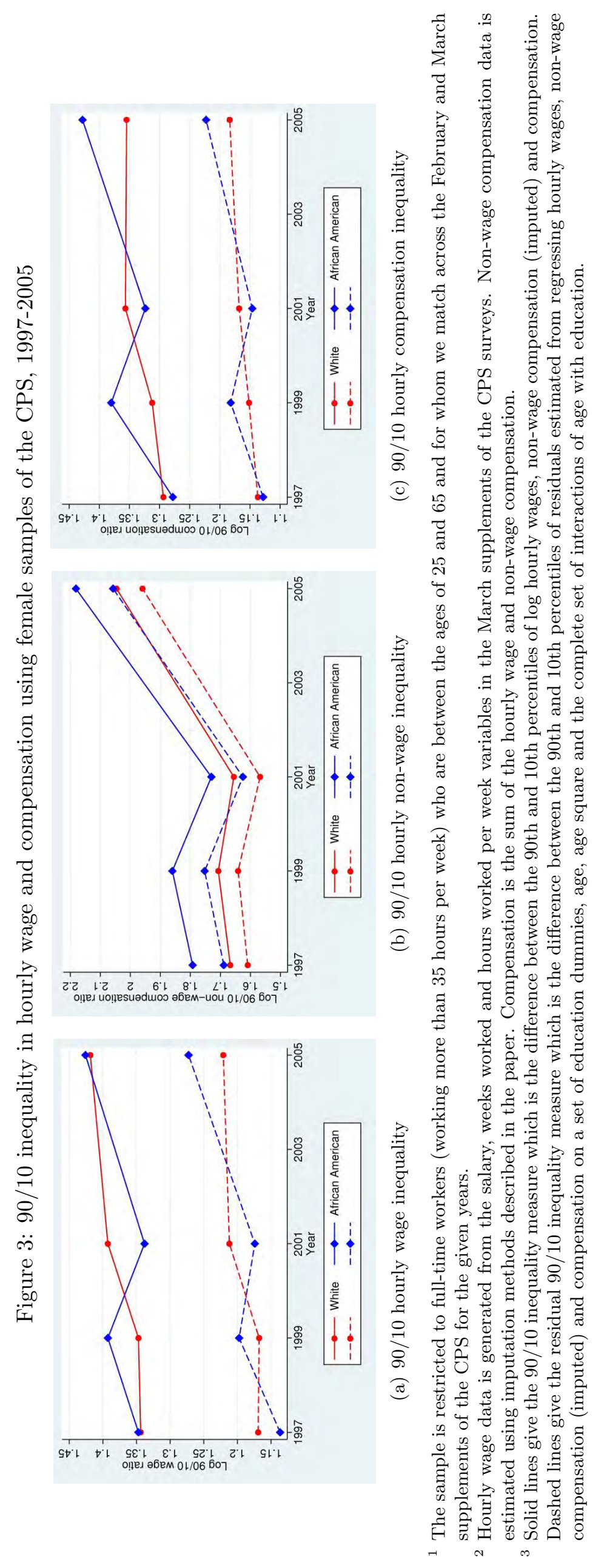




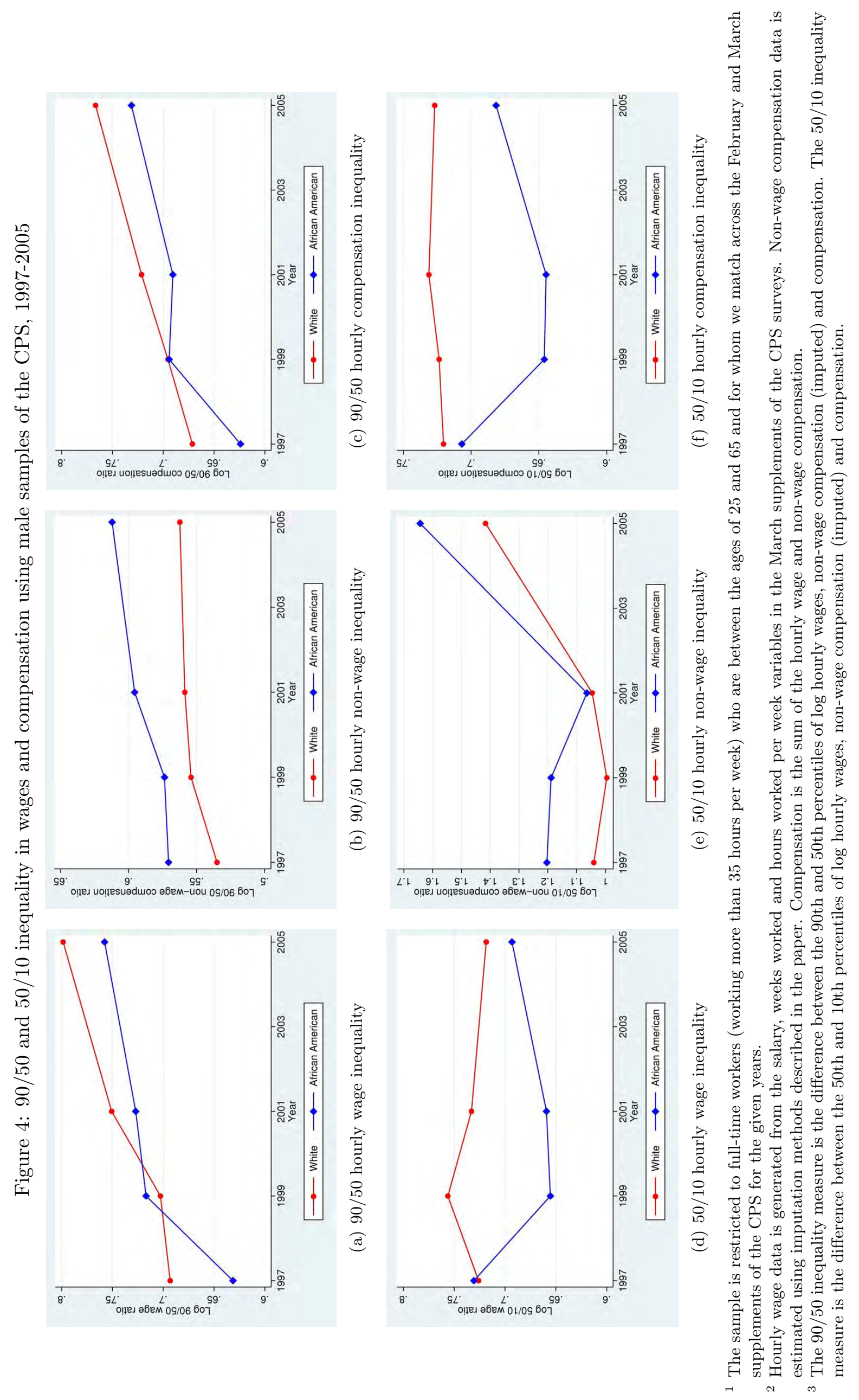




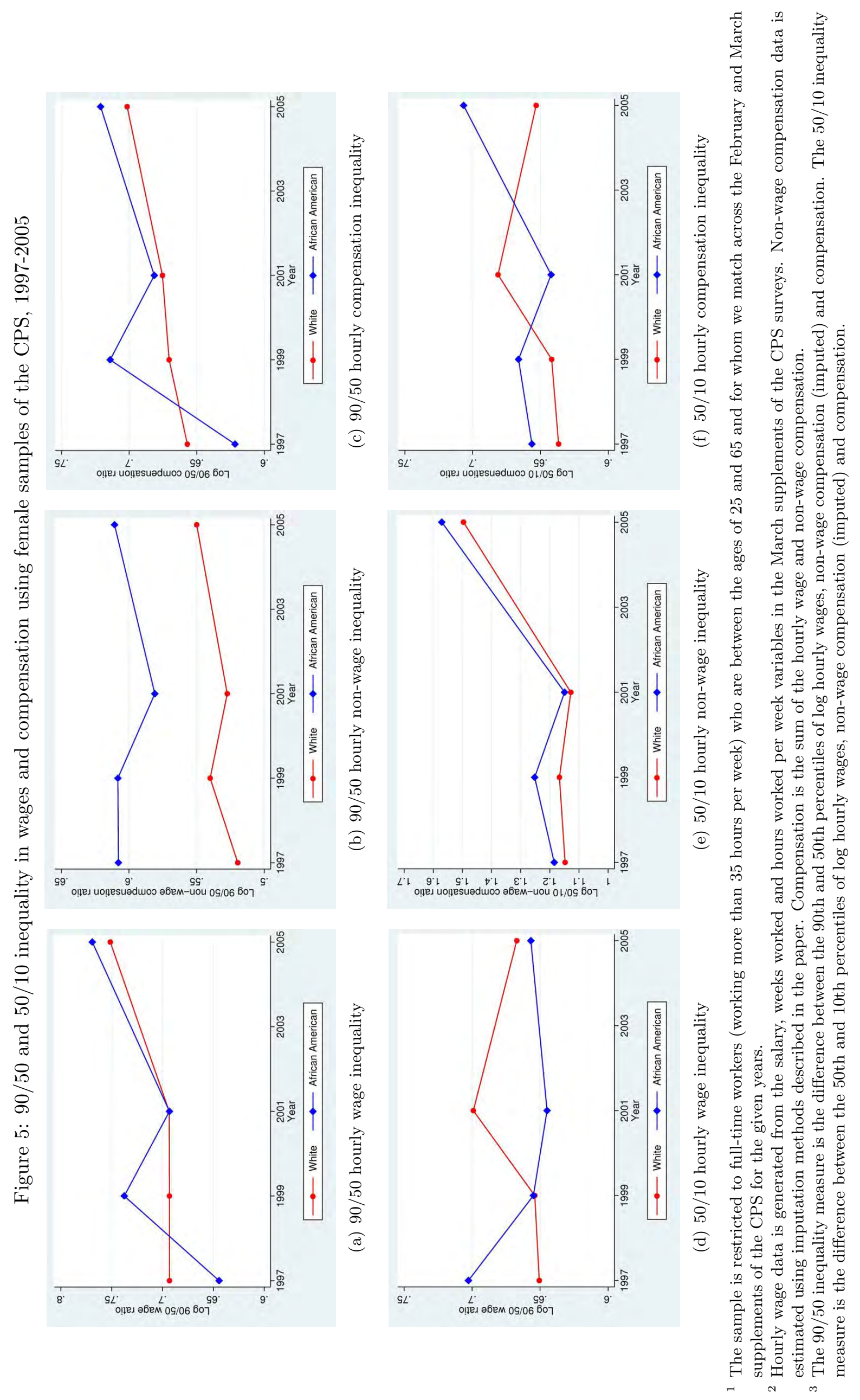




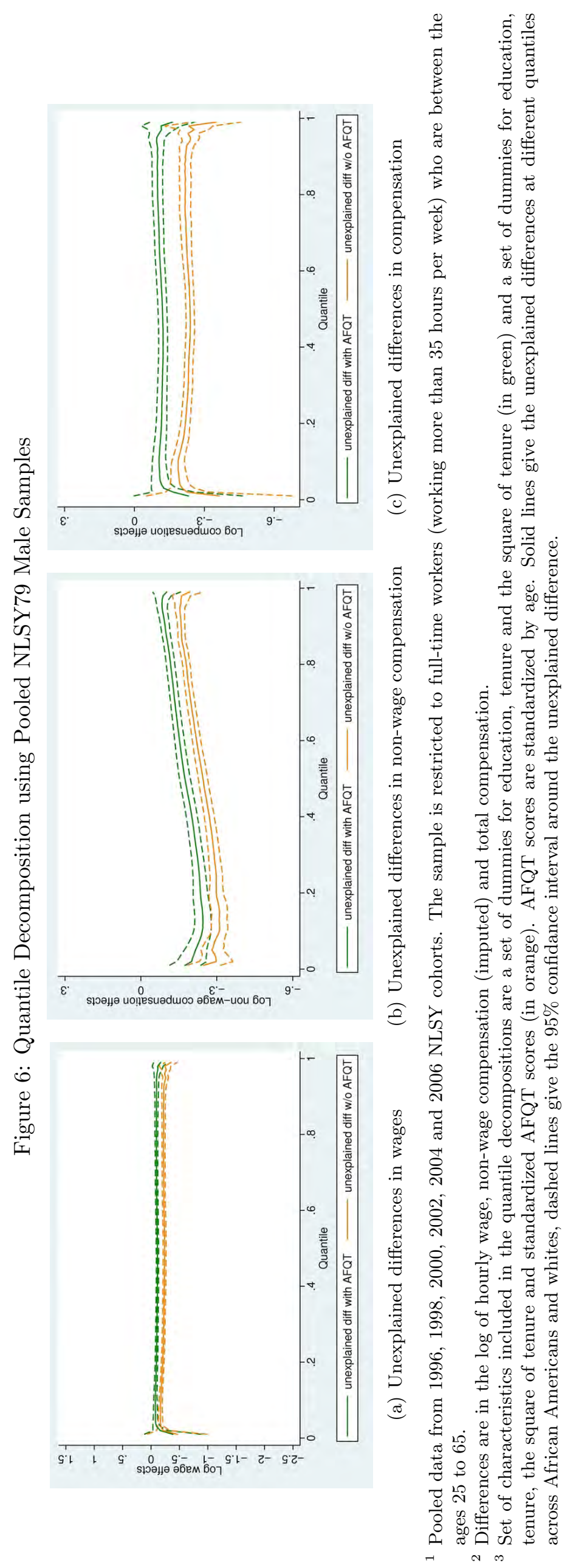




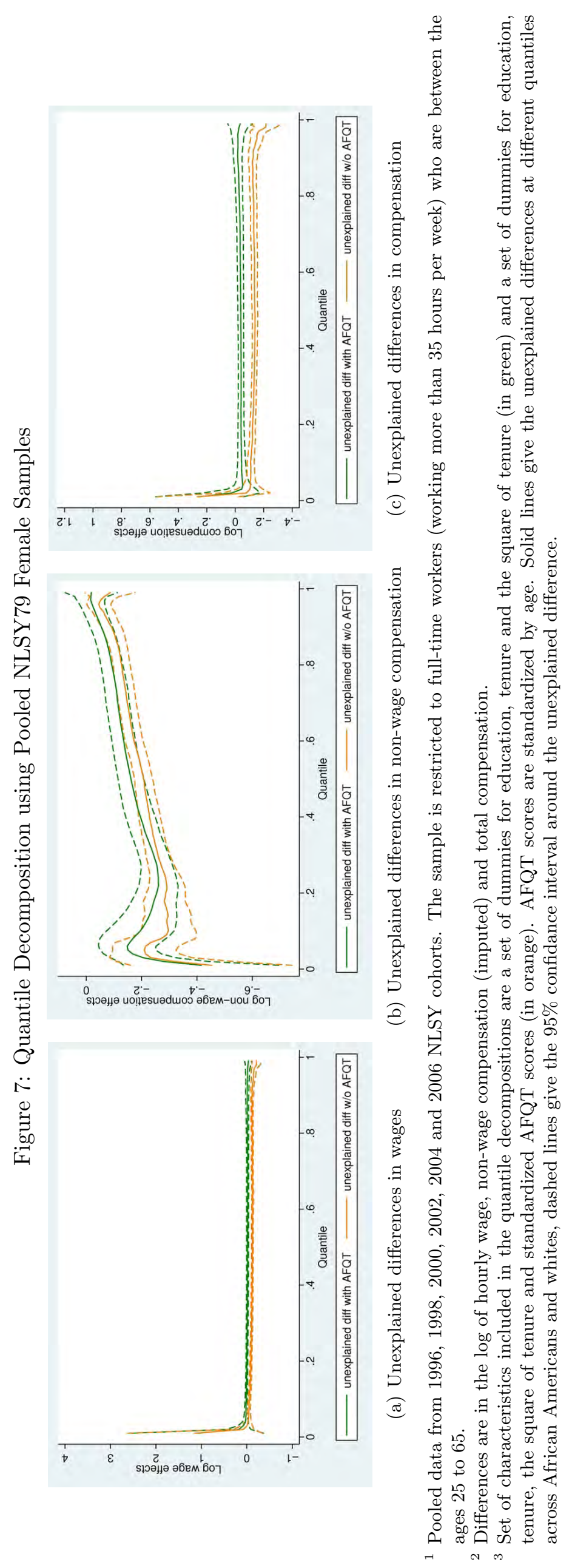




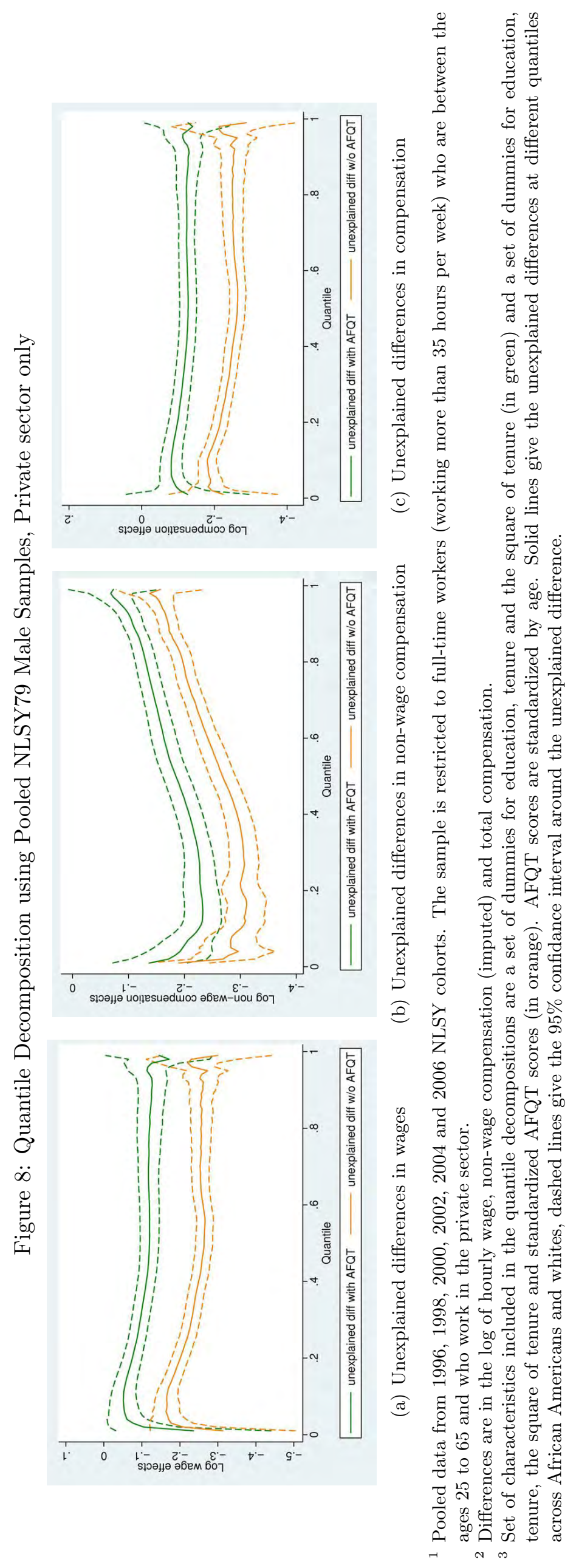




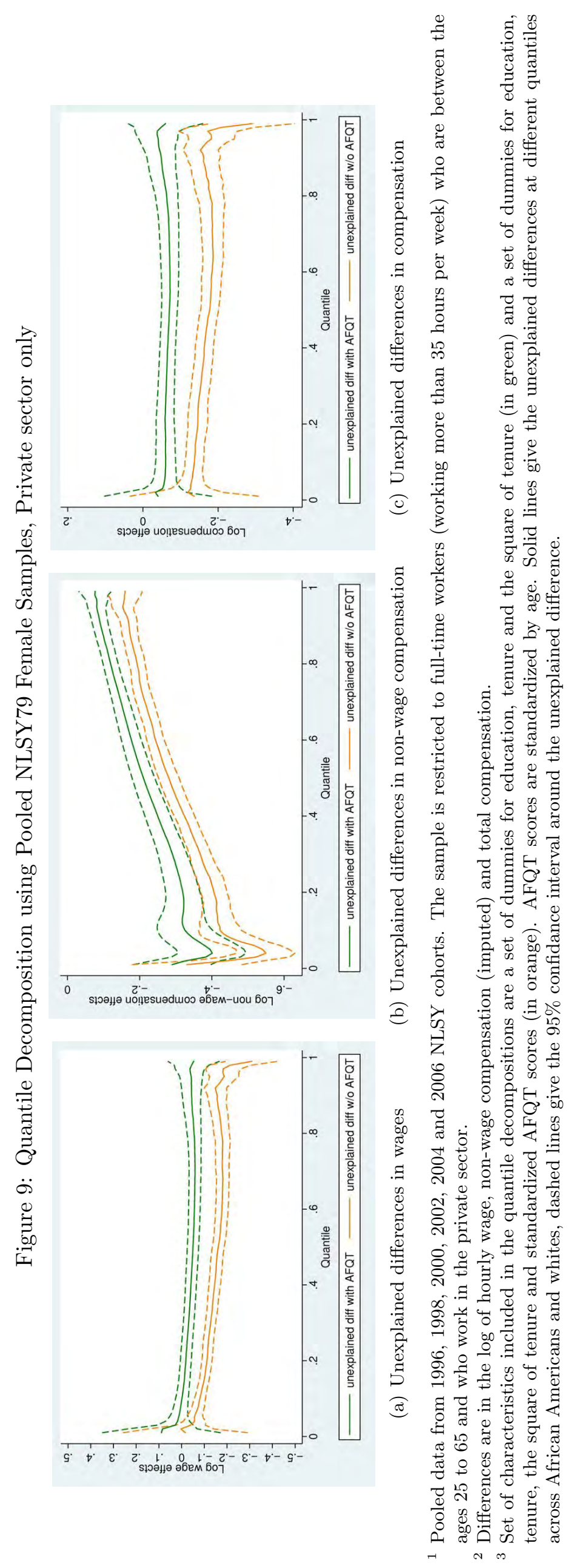




\section{Appendix Tables}

Table A1: Reasons for Non-Takeup in Employer-Provided Health Insurance

\begin{tabular}{lcccc}
\hline & \multicolumn{2}{c}{ Men } & \multicolumn{2}{c}{ Women } \\
& White & Black & White & Black \\
\hline Reason for not taking up & & & & \\
Another plan & 0.5933 & 0.4892 & 0.7399 & 0.5817 \\
Traded for higher pay & 0.0048 & 0.0039 & 0.0060 & 0.0050 \\
Too expensive & 0.2140 & 0.2750 & 0.1438 & 0.2562 \\
Don't need Health Insurance & 0.0157 & 0.0236 & 0.0094 & 0.0111 \\
Pre-existing condition & 0.0053 & 0.0039 & 0.0018 & 0.0012 \\
Havent worked for long & 0.0662 & 0.0864 & 0.0358 & 0.0656 \\
Contract or temp employee & 0.0017 & 0.0059 & 0.0006 & 0.0000 \\
Other & 0.0991 & 0.1120 & 0.0627 & 0.0792 \\
& 5874 & 509 & 7832 & 808 \\
\hline${ }^{1}$ Data come from the February Supplements of the 1995, & $1997,1999,2001$ & and 2005 \\
Current Population Surveys. & & & \\
${ }^{2}$ As a fraction of White (Black) Men (Women) who do not receive HI from the employer \\
${ }^{3}$ Includes all workers between ages 25 and 65 who work more than 35 hours per week, are \\
not enrolled in school and not in the armed forces & & &
\end{tabular}


Table A2: Individual level characteristics, CPS data

\begin{tabular}{|c|c|c|c|c|}
\hline & \multicolumn{2}{|c|}{ Men } & \multicolumn{2}{|c|}{ Women } \\
\hline & White & Black & White & Black \\
\hline \multirow[t]{2}{*}{$\mathrm{HI}$} & 0.9013 & 0.8712 & 0.8525 & 0.8500 \\
\hline & $(0.0016)$ & $(0.0069)$ & $(0.0025)$ & $(0.0088)$ \\
\hline \multirow[t]{2}{*}{ Pension } & 0.7357 & 0.6747 & 0.7104 & 0.6922 \\
\hline & $(0.0023)$ & $(0.0097)$ & $(0.0032)$ & $(0.0113)$ \\
\hline \multirow[t]{2}{*}{ Both HI and Pension } & 0.7101 & 0.6352 & 0.6618 & 0.6440 \\
\hline & $(0.0024)$ & $(0.0099)$ & $(0.0033)$ & $(0.0118)$ \\
\hline \multicolumn{5}{|l|}{ Education } \\
\hline \multirow[t]{2}{*}{ Below High School } & 0.0344 & 0.0323 & 0.0201 & 0.0096 \\
\hline & $(0.0010)$ & $(0.0036)$ & $(0.0010)$ & $(0.0024)$ \\
\hline \multirow[t]{2}{*}{ Some High School } & 0.0599 & 0.0927 & 0.0428 & 0.0729 \\
\hline & $(0.0012)$ & $(0.0060)$ & $(0.0014)$ & $(0.0064)$ \\
\hline \multirow[t]{2}{*}{ High School } & 0.3189 & 0.3912 & 0.3569 & 0.3675 \\
\hline & $(0.0024)$ & $(0.0101)$ & $(0.0033)$ & $(0.0118)$ \\
\hline \multirow[t]{2}{*}{ Some College } & 0.2667 & 0.2989 & 0.3097 & 0.3325 \\
\hline & $(0.0023)$ & $(0.0094)$ & $(0.0032)$ & $(0.0116)$ \\
\hline \multirow[t]{2}{*}{ College graduate and above } & 0.3201 & 0.1849 & 0.2705 & 0.2175 \\
\hline & $(0.0024)$ & $(0.0080)$ & $(0.0031)$ & $(0.0101)$ \\
\hline \multirow[t]{2}{*}{ Age } & 43 & 43 & 42 & 41 \\
\hline & $(0.0512)$ & $(0.2003)$ & $(0.0676)$ & $(0.2320)$ \\
\hline \multicolumn{5}{|l|}{ Region } \\
\hline \multirow[t]{2}{*}{ Northeast } & 0.2182 & 0.1752 & 0.2191 & 0.1910 \\
\hline & $(0.0022)$ & $(0.0078)$ & $(0.0029)$ & $(0.0097)$ \\
\hline \multirow[t]{2}{*}{ Midwest } & 0.2758 & 0.1743 & 0.2839 & 0.1711 \\
\hline & $(0.0023)$ & $(0.0078)$ & $(0.0031)$ & $(0.0092)$ \\
\hline \multirow[t]{2}{*}{ South } & 0.2875 & 0.5595 & 0.2969 & 0.5524 \\
\hline & $(0.0024)$ & $(0.0102)$ & $(0.0032)$ & $(0.0122)$ \\
\hline \multirow[t]{2}{*}{ West } & 0.2186 & 0.0910 & 0.2000 & 0.0855 \\
\hline & $(0.0022)$ & $(0.0059)$ & $(0.0028)$ & $(0.0069)$ \\
\hline \multicolumn{5}{|l|}{ Children } \\
\hline \multirow[t]{2}{*}{ \# of children younger than $6=1,2$} & 0.2606 & 0.2564 & 0.1725 & 0.2108 \\
\hline & $(0.0023)$ & $(0.0090)$ & $(0.0026)$ & $(0.0100)$ \\
\hline \multirow[t]{2}{*}{ \# of children younger than $6=3,4$} & 0.0114 & 0.0089 & 0.0026 & 0.0024 \\
\hline & $(0.0006)$ & $(0.0019)$ & $(0.0004)$ & $(0.0012)$ \\
\hline \multirow[t]{2}{*}{$\#$ of children younger than $6=5,6$} & 0.0000 & 0.0004 & 0.0000 & 0.0006 \\
\hline & $(0.0000)$ & $(0.0004)$ & $(0.0000)$ & $(0.0006)$ \\
\hline \multirow[t]{2}{*}{ Spouse Wages } & 20586 & 21796 & 42913 & 34809 \\
\hline & $(143)$ & $(530)$ & $(318)$ & $(812)$ \\
\hline $\mathrm{N}$ & 51736 & 4271 & 35190 & 4702 \\
\hline
\end{tabular}


Table A3: Firm level characteristics, CPS data

\begin{tabular}{|c|c|c|c|c|}
\hline & \multicolumn{2}{|c|}{ Men } & \multicolumn{2}{|c|}{ Women } \\
\hline & White & Black & White & Black \\
\hline Union Membership & $\begin{array}{c}0.1493 \\
(0.0019)\end{array}$ & $\begin{array}{c}0.2245 \\
(0.0086)\end{array}$ & $\begin{array}{c}0.0697 \\
(0.0018)\end{array}$ & $\begin{array}{c}0.1416 \\
(0.0086)\end{array}$ \\
\hline \multicolumn{5}{|l|}{ Firm Size } \\
\hline$<25$ employees & $\begin{array}{c}0.1985 \\
(0.0021)\end{array}$ & $\begin{array}{c}0.1514 \\
(0.0074)\end{array}$ & $\begin{array}{c}0.2093 \\
(0.0028)\end{array}$ & $\begin{array}{c}0.1301 \\
(0.0083)\end{array}$ \\
\hline 25 - 99 employees & $\begin{array}{c}0.1600 \\
(0.0019)\end{array}$ & $\begin{array}{c}0.1356 \\
(0.0071)\end{array}$ & $\begin{array}{c}0.1511 \\
(0.0025)\end{array}$ & $\begin{array}{c}0.1084 \\
(0.0076)\end{array}$ \\
\hline $100-499$ employees & $\begin{array}{c}0.1757 \\
(0.0020)\end{array}$ & $\begin{array}{c}0.1628 \\
(0.0076)\end{array}$ & $\begin{array}{c}0.1758 \\
(0.0027)\end{array}$ & $\begin{array}{c}0.1620 \\
(0.0090)\end{array}$ \\
\hline $500-999$ employees & $\begin{array}{c}0.0639 \\
(0.0013)\end{array}$ & $\begin{array}{c}0.0753 \\
(0.0054)\end{array}$ & $\begin{array}{c}0.0682 \\
(0.0018)\end{array}$ & $\begin{array}{c}0.0934 \\
(0.0071)\end{array}$ \\
\hline $1000+$ employees & $\begin{array}{c}0.4019 \\
(0.0026)\end{array}$ & $\begin{array}{c}0.4749 \\
(0.0103)\end{array}$ & $\begin{array}{c}0.3955 \\
(0.0034)\end{array}$ & $\begin{array}{c}0.5060 \\
(0.0123)\end{array}$ \\
\hline \multicolumn{5}{|l|}{ Occupation } \\
\hline Executive, Professional & $\begin{array}{c}0.3655 \\
(0.0025)\end{array}$ & $\begin{array}{c}0.2117 \\
(0.0084)\end{array}$ & $\begin{array}{c}0.4170 \\
(0.0034)\end{array}$ & $\begin{array}{c}0.3277 \\
(0.0115)\end{array}$ \\
\hline Sales & $\begin{array}{c}0.1258 \\
(0.0017)\end{array}$ & $\begin{array}{c}0.0702 \\
(0.0053)\end{array}$ & $\begin{array}{c}0.1148 \\
(0.0022)\end{array}$ & $\begin{array}{c}0.0795 \\
(0.0066)\end{array}$ \\
\hline Administrative & $\begin{array}{c}0.0439 \\
(0.0011)\end{array}$ & $\begin{array}{c}0.0727 \\
(0.0054)\end{array}$ & $\begin{array}{c}0.2741 \\
(0.0031)\end{array}$ & $\begin{array}{c}0.2488 \\
(0.0106)\end{array}$ \\
\hline Farming, Fisheries and Forestry & $\begin{array}{c}0.0125 \\
(0.0006)\end{array}$ & $\begin{array}{c}0.0102 \\
(0.0021)\end{array}$ & $\begin{array}{c}0.0038 \\
(0.0004)\end{array}$ & $\begin{array}{c}0.0006 \\
(0.0006)\end{array}$ \\
\hline Factory Labor and Construction & $\begin{array}{c}0.3332 \\
(0.0025)\end{array}$ & $\begin{array}{c}0.3827 \\
(0.0100)\end{array}$ & $\begin{array}{c}0.0908 \\
(0.0020)\end{array}$ & $\begin{array}{c}0.1404 \\
(0.0085)\end{array}$ \\
\hline Services & $\begin{array}{c}0.0391 \\
(0.0010)\end{array}$ & $\begin{array}{c}0.0982 \\
(0.0061)\end{array}$ & $\begin{array}{c}0.0915 \\
(0.0020)\end{array}$ & $\begin{array}{c}0.1892 \\
(0.0096)\end{array}$ \\
\hline Transportation & $\begin{array}{c}0.0800 \\
(0.0014)\end{array}$ & $\begin{array}{c}0.1543 \\
(0.0075)\end{array}$ & $\begin{array}{c}0.0081 \\
(0.0006)\end{array}$ & $\begin{array}{c}0.0139 \\
(0.0029)\end{array}$ \\
\hline \multicolumn{5}{|l|}{ Industry } \\
\hline Agriculture, forestry & $\begin{array}{c}0.0140 \\
(0.0006)\end{array}$ & $\begin{array}{c}0.0060 \\
(0.0016)\end{array}$ & $\begin{array}{c}0.0057 \\
(0.0005)\end{array}$ & $\begin{array}{c}0.0006 \\
(0.0006)\end{array}$ \\
\hline Mining & $\begin{array}{c}0.0187 \\
(0.0007)\end{array}$ & $\begin{array}{c}0.0068 \\
(0.0017)\end{array}$ & $\begin{array}{c}0.0038 \\
(0.0004)\end{array}$ & $\begin{array}{c}0.0018 \\
(0.0010)\end{array}$ \\
\hline Construction & $\begin{array}{c}0.0939 \\
(0.0015)\end{array}$ & $\begin{array}{c}0.0629 \\
(0.0050)\end{array}$ & $\begin{array}{c}0.0163 \\
(0.0009)\end{array}$ & $\begin{array}{c}0.0084 \\
(0.0022)\end{array}$ \\
\hline Manufacturing & $\begin{array}{c}0.2935 \\
(0.0024)\end{array}$ & $\begin{array}{c}0.3261 \\
(0.0097)\end{array}$ & $\begin{array}{c}0.1597 \\
(0.0026)\end{array}$ & $\begin{array}{c}0.1747 \\
(0.0093)\end{array}$ \\
\hline Wholesale and retail trade & $\begin{array}{c}0.1878 \\
(0.0020)\end{array}$ & $\begin{array}{c}0.1603 \\
(0.0076)\end{array}$ & $\begin{array}{c}0.1720 \\
(0.0026)\end{array}$ & $\begin{array}{c}0.1096 \\
(0.0077)\end{array}$ \\
\hline Transportation and utilities & $\begin{array}{c}0.0867 \\
(0.0015)\end{array}$ & $\begin{array}{c}0.1288 \\
(0.0069)\end{array}$ & $\begin{array}{c}0.0300 \\
(0.0012)\end{array}$ & $\begin{array}{c}0.0265 \\
(0.0039)\end{array}$ \\
\hline Information & $\begin{array}{c}0.0246 \\
(0.0008)\end{array}$ & $\begin{array}{c}0.0319 \\
(0.0036)\end{array}$ & $\begin{array}{c}0.0205 \\
(0.0010)\end{array}$ & $\begin{array}{c}0.0343 \\
(0.0045)\end{array}$ \\
\hline Financial activities & $\begin{array}{c}0.0658 \\
(0.0013)\end{array}$ & $\begin{array}{c}0.0519 \\
(0.0046)\end{array}$ & $\begin{array}{c}0.1394 \\
(0.0024)\end{array}$ & $\begin{array}{c}0.1373 \\
(0.0085)\end{array}$ \\
\hline Professional and business & $\begin{array}{c}0.0756 \\
(0.0014)\end{array}$ & $\begin{array}{c}0.0740 \\
(0.0054)\end{array}$ & $\begin{array}{c}0.0662 \\
(0.0017)\end{array}$ & $\begin{array}{c}0.0663 \\
(0.0061)\end{array}$ \\
\hline Educational and health services & $\begin{array}{c}0.0635 \\
(0.0013)\end{array}$ & $\begin{array}{c}0.0850 \\
(0.0058)\end{array}$ & $\begin{array}{c}0.2884 \\
(0.0032)\end{array}$ & $\begin{array}{c}0.3500 \\
(0.0117)\end{array}$ \\
\hline Leisure and hospitality & $\begin{array}{c}0.0549 \\
(0.0012)\end{array}$ & $\begin{array}{c}0.0417 \\
(0.0041)\end{array}$ & $\begin{array}{c}0.0661 \\
(0.0017)\end{array}$ & $\begin{array}{c}0.0452 \\
(0.0051)\end{array}$ \\
\hline Other services & $\begin{array}{c}0.0210 \\
(0.0008)\end{array}$ & $\begin{array}{c}0.0247 \\
(0.0032)\end{array}$ & $\begin{array}{c}0.0319 \\
(0.0012)\end{array}$ & $\begin{array}{c}0.0452 \\
(0.0051)\end{array}$ \\
\hline $\mathrm{N}$ & 51736 & 4271 & 35190 & 4702 \\
\hline
\end{tabular}

\footnotetext{
${ }^{1}$ Data from 1997, 1999, 2001 and 2005 cohorts of the CPS, full time workers in the private sector only.

${ }^{2}$ Standard error in parentheses.
} 
Table A4: Individual level characteristics, pooled NLSY data

\begin{tabular}{|c|c|c|c|c|}
\hline & \multicolumn{2}{|c|}{ Men } & \multicolumn{2}{|c|}{ Women } \\
\hline & White & Black & White & Black \\
\hline \multirow[t]{2}{*}{$\mathrm{HI}$} & 0.8620 & 0.7925 & 0.8523 & 0.8468 \\
\hline & $(0.0036)$ & $(0.0065)$ & $(0.0042)$ & $(0.0060)$ \\
\hline \multirow[t]{2}{*}{ Pension } & 0.7508 & 0.6751 & 0.7468 & 0.7666 \\
\hline & $(0.0045)$ & $(0.0076)$ & $(0.0052)$ & $(0.0070)$ \\
\hline \multirow[t]{2}{*}{ Both HI and Pension } & 0.7375 & 0.6596 & 0.7255 & 0.7471 \\
\hline & $(0.0046)$ & $(0.0076)$ & $(0.0053)$ & $(0.0072)$ \\
\hline \multicolumn{5}{|l|}{ Education } \\
\hline \multirow[t]{2}{*}{ Below High School } & 0.0235 & 0.0123 & 0.0150 & 0.0066 \\
\hline & $(0.0016)$ & $(0.0017)$ & $(0.0014)$ & $(0.0013)$ \\
\hline \multirow[t]{2}{*}{ Some High School } & 0.0827 & 0.0980 & 0.0485 & 0.0601 \\
\hline & $(0.0029)$ & $(0.0048)$ & $(0.0025)$ & $(0.0039)$ \\
\hline \multirow[t]{2}{*}{ High School } & 0.4276 & 0.5359 & 0.4205 & 0.3951 \\
\hline & $(0.0052)$ & $(0.0080)$ & $(0.0059)$ & $(0.0081)$ \\
\hline \multirow[t]{2}{*}{ Some College } & 0.2021 & 0.2169 & 0.2623 & 0.3522 \\
\hline & $(0.0042)$ & $(0.0066)$ & $(0.0052)$ & $(0.0079)$ \\
\hline \multirow[t]{2}{*}{ College Graduate and Above } & 0.2640 & 0.1365 & 0.2535 & 0.1857 \\
\hline & $(0.0046)$ & $(0.0055)$ & $(0.0052)$ & $(0.0064)$ \\
\hline \multirow[t]{2}{*}{ Age } & 39 & 38 & 39 & 39 \\
\hline & $(0.0382)$ & $(0.0576)$ & $(0.0435)$ & $(0.0591)$ \\
\hline \multicolumn{5}{|l|}{ Region } \\
\hline \multirow[t]{2}{*}{ Northeast } & 0.1688 & 0.1299 & 0.1459 & 0.1169 \\
\hline & $(0.0039)$ & $(0.0054)$ & $(0.0042)$ & $(0.0053)$ \\
\hline \multirow[t]{2}{*}{ North Central } & 0.2875 & 0.1626 & 0.2588 & 0.1709 \\
\hline & $(0.0047)$ & $(0.0059)$ & $(0.0052)$ & $(0.0062)$ \\
\hline \multirow[t]{2}{*}{ South } & 0.3240 & 0.6290 & 0.3871 & 0.6480 \\
\hline & $(0.0049)$ & $(0.0078)$ & $(0.0058)$ & $(0.0079)$ \\
\hline \multirow[t]{2}{*}{ West } & 0.2195 & 0.0783 & 0.2080 & 0.0640 \\
\hline & $(0.0043)$ & $(0.0043)$ & $(0.0048)$ & $(0.0040)$ \\
\hline \multirow[t]{2}{*}{ Child } & 1.3515 & 0.9744 & 1.3647 & 1.5449 \\
\hline & $(0.0136)$ & $(0.0203)$ & $(0.0137)$ & $(0.0206)$ \\
\hline \multirow[t]{2}{*}{ Spouse Wage } & 15290 & 10496 & 27997 & 11578 \\
\hline & $(268)$ & $(305)$ & $(426)$ & $(371)$ \\
\hline \multirow[t]{2}{*}{ Standardized AFQT score } & 0.3302 & -0.6356 & 0.1995 & -0.5857 \\
\hline & $(0.0107)$ & $(0.0123)$ & $(0.0111)$ & $(0.0117)$ \\
\hline $\mathrm{N}$ & 1,607 & 652 & 1,284 & 678 \\
\hline
\end{tabular}


Table A5: Firm level characteristics, pooled NLSY data

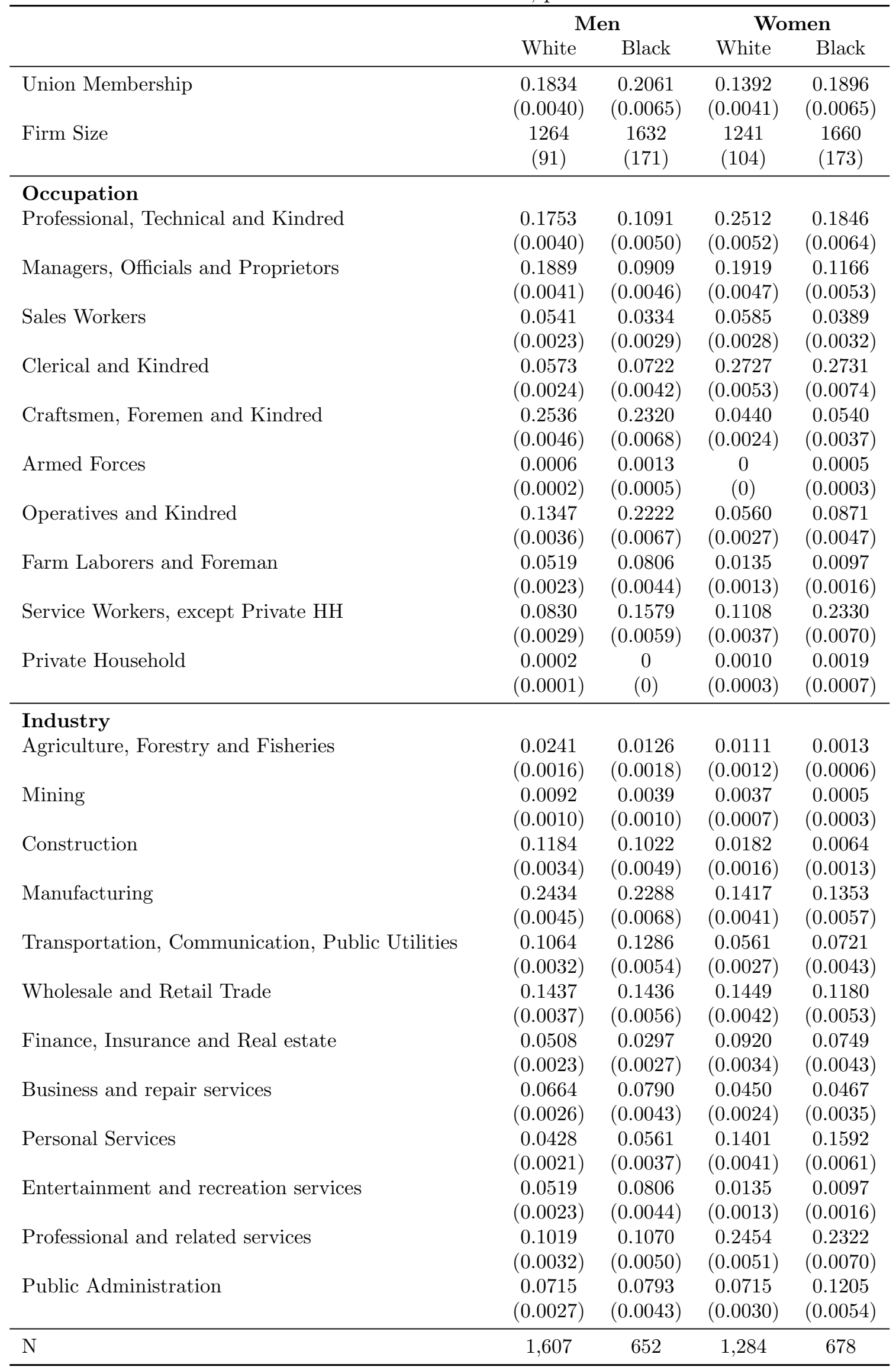

${ }^{1}$ Data from pooled 1996, 1998, 2000, 2002, 2004 cohorts of the NLSY, full time workers only.

${ }^{2}$ Standard error in parentheses. 
Table A6: Individual level characteristics, pooled NLSY data for private sector workers

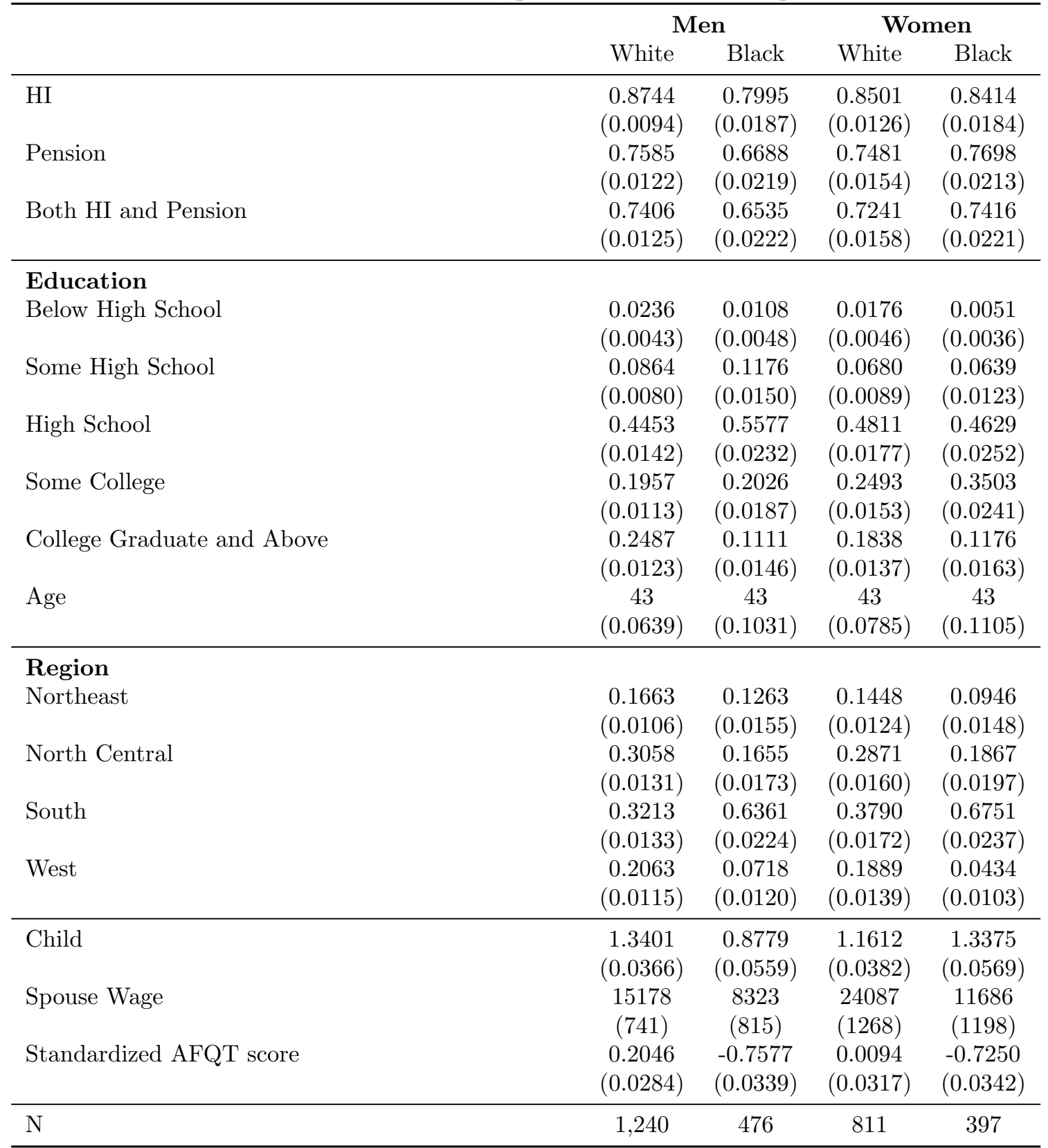

${ }^{1}$ Data from pooled 1996, 1998, 2000, 2002, 2004 cohorts of the NLSY, full time workers in the private sector only.

2 Standard error in parentheses. 
Table A7: Firm level characteristics, pooled NLSY data for private sector workers

\begin{tabular}{|c|c|c|c|c|}
\hline & \multicolumn{2}{|c|}{ Men } & \multicolumn{2}{|c|}{ Women } \\
\hline & White & Black & White & Black \\
\hline \multirow[t]{2}{*}{ Union Membership } & 0.1484 & 0.1655 & 0.0516 & 0.1125 \\
\hline & $(0.0101)$ & $(0.0173)$ & $(0.0078)$ & $(0.0160)$ \\
\hline Firm Size & $\begin{array}{c}593 \\
(94.5119)\end{array}$ & $\begin{array}{c}1621 \\
(488.711)\end{array}$ & $\begin{array}{c}676 \\
(162.7418)\end{array}$ & $\begin{array}{c}1903 \\
(581.6746)\end{array}$ \\
\hline \multicolumn{5}{|l|}{ Occupation } \\
\hline Professional, Technical and Kindred & $\begin{array}{c}0.1190 \\
(0.0092)\end{array}$ & $\begin{array}{c}0.0522 \\
(0.0104)\end{array}$ & $\begin{array}{c}0.1246 \\
(0.0117)\end{array}$ & $\begin{array}{c}0.1176 \\
(0.0163)\end{array}$ \\
\hline Managers, Officials and Proprietors & $\begin{array}{c}0.2055 \\
(0.0115)\end{array}$ & $\begin{array}{c}0.0893 \\
(0.0133)\end{array}$ & $\begin{array}{c}0.2292 \\
(0.0149)\end{array}$ & $\begin{array}{c}0.1278 \\
(0.0169)\end{array}$ \\
\hline Sales Workers & $\begin{array}{c}0.0946 \\
(0.0083)\end{array}$ & $\begin{array}{c}0.0501 \\
(0.0101)\end{array}$ & $\begin{array}{c}0.1234 \\
(0.0116)\end{array}$ & $\begin{array}{c}0.0792 \\
(0.0136)\end{array}$ \\
\hline Clerical and Kindred & $\begin{array}{c}0.0546 \\
(0.0064)\end{array}$ & $\begin{array}{c}0.0675 \\
(0.0117)\end{array}$ & $\begin{array}{c}0.2821 \\
(0.0159)\end{array}$ & $\begin{array}{c}0.2404 \\
(0.0216)\end{array}$ \\
\hline Craftsmen, Foremen and Kindred & $\begin{array}{c}0.3564 \\
(0.0136)\end{array}$ & $\begin{array}{c}0.3790 \\
(0.0226)\end{array}$ & $\begin{array}{c}0.1045 \\
(0.0108)\end{array}$ & $\begin{array}{c}0.1662 \\
(0.0188)\end{array}$ \\
\hline Operatives and Kindred & $\begin{array}{c}0.1101 \\
(0.0089)\end{array}$ & $\begin{array}{c}0.2156 \\
(0.0192)\end{array}$ & $\begin{array}{c}0.0251 \\
(0.0055)\end{array}$ & $\begin{array}{c}0.0281 \\
(0.0083)\end{array}$ \\
\hline Farm Laborers and Foreman & $\begin{array}{c}0.0114 \\
(0.0030)\end{array}$ & $\begin{array}{c}0.0043 \\
(0.0030)\end{array}$ & $\begin{array}{c}0 \\
(0)\end{array}$ & $\begin{array}{c}0 \\
(0)\end{array}$ \\
\hline Service Workers, except Private HH & $\begin{array}{c}0.0481 \\
(0.0061) \\
\end{array}$ & $\begin{array}{c}0.1416 \\
(0.0162) \\
\end{array}$ & $\begin{array}{c}0.1108 \\
(0.0111) \\
\end{array}$ & $\begin{array}{c}0.2404 \\
(0.0216) \\
\end{array}$ \\
\hline \multicolumn{5}{|l|}{ Industry } \\
\hline Agriculture, Forestry and Fisheries & $\begin{array}{c}0.0163 \\
(0.0036)\end{array}$ & $\begin{array}{c}0.0021 \\
(0.0021)\end{array}$ & $\begin{array}{c}0.0037 \\
(0.0021)\end{array}$ & $\begin{array}{c}0 \\
(0)\end{array}$ \\
\hline Mining & $\begin{array}{c}0.0097 \\
(0.0028)\end{array}$ & $\begin{array}{c}0.0043 \\
(0.0030)\end{array}$ & $\begin{array}{c}0.0012 \\
(0.0012)\end{array}$ & $\begin{array}{c}0 \\
(0)\end{array}$ \\
\hline Construction & $\begin{array}{c}0.1427 \\
(0.0099)\end{array}$ & $\begin{array}{c}0.1067 \\
(0.0144)\end{array}$ & $\begin{array}{c}0.0277 \\
(0.0058)\end{array}$ & $\begin{array}{c}0.0127 \\
(0.0056)\end{array}$ \\
\hline Manufacturing & $\begin{array}{c}0.2805 \\
(0.0128)\end{array}$ & $\begin{array}{c}0.2549 \\
(0.0203)\end{array}$ & $\begin{array}{c}0.1750 \\
(0.0134)\end{array}$ & $\begin{array}{c}0.1841 \\
(0.0196)\end{array}$ \\
\hline Transportation, Communication, Public Utilities & $\begin{array}{c}0.1223 \\
(0.0093)\end{array}$ & $\begin{array}{c}0.1241 \\
(0.0154)\end{array}$ & $\begin{array}{c}0.0818 \\
(0.0097)\end{array}$ & $\begin{array}{c}0.0920 \\
(0.0146)\end{array}$ \\
\hline Wholesale and Retail Trade & $\begin{array}{c}0.1761 \\
(0.0108)\end{array}$ & $\begin{array}{c}0.1742 \\
(0.0177)\end{array}$ & $\begin{array}{c}0.1863 \\
(0.0138)\end{array}$ & $\begin{array}{c}0.1381 \\
(0.0174)\end{array}$ \\
\hline Finance, Insurance and Real estate & $\begin{array}{c}0.0628 \\
(0.0069)\end{array}$ & $\begin{array}{c}0.0239 \\
(0.0071)\end{array}$ & $\begin{array}{c}0.1372 \\
(0.0122)\end{array}$ & $\begin{array}{c}0.1176 \\
(0.0163)\end{array}$ \\
\hline Business and repair services & $\begin{array}{c}0.0309 \\
(0.0049)\end{array}$ & $\begin{array}{c}0.0457 \\
(0.0097)\end{array}$ & $\begin{array}{c}0.0125 \\
(0.0039)\end{array}$ & $\begin{array}{c}0.0153 \\
(0.0062)\end{array}$ \\
\hline Personal Services & $\begin{array}{c}0.0318 \\
(0.0050)\end{array}$ & $\begin{array}{c}0.0457 \\
(0.0097)\end{array}$ & $\begin{array}{c}0.1700 \\
(0.0133)\end{array}$ & $\begin{array}{c}0.2429 \\
(0.0217)\end{array}$ \\
\hline Entertainment and recreation services & $\begin{array}{c}0.0293 \\
(0.0048)\end{array}$ & $\begin{array}{c}0.0893 \\
(0.0133)\end{array}$ & $\begin{array}{c}0.0856 \\
(0.0099)\end{array}$ & $\begin{array}{c}0.1099 \\
(0.0158)\end{array}$ \\
\hline Professional and related services & $\begin{array}{c}0.0962 \\
(0.0084)\end{array}$ & $\begin{array}{c}0.1263 \\
(0.0155)\end{array}$ & $\begin{array}{c}0.1158 \\
(0.0113)\end{array}$ & $\begin{array}{c}0.0869 \\
(0.0142)\end{array}$ \\
\hline Public administration & $\begin{array}{c}0.0008 \\
(0.0008)\end{array}$ & $\begin{array}{c}0.0021 \\
(0.0021)\end{array}$ & $\begin{array}{c}0.0025 \\
(0.0017)\end{array}$ & $\begin{array}{c}0 \\
(0)\end{array}$ \\
\hline $\mathrm{N}$ & 1,240 & 476 & 811 & 397 \\
\hline
\end{tabular}

${ }^{1}$ Data from pooled 1996, 1998, 2000, 2002, 2004 cohorts of the NLSY, full time workers in the private sector only.

${ }^{2}$ Standard error in parentheses. 